\title{
Cadherins in development: cell adhesion, sorting, and tissue morphogenesis
}

\author{
Jennifer M. Halbleib and W. James Nelson ${ }^{1}$ \\ Departments of Biological Sciences and Molecular and Cellular Physiology, Stanford University, \\ Stanford, California 94305, USA
}

Tissue morphogenesis during development is dependent on activities of the cadherin family of cell-cell adhesion proteins that includes classical cadherins, protocadherins, and atypical cadherins (Fat, Dachsous, and Flamingo). The extracellular domain of cadherins contains characteristic repeats that regulate homophilic and heterophilic interactions during adhesion and cell sorting. Although cadherins may have originated to facilitate mechanical cell-cell adhesion, they have evolved to function in many other aspects of morphogenesis. These additional roles rely on cadherin interactions with a wide range of binding partners that modify their expression and adhesion activity by local regulation of the actin cytoskeleton and diverse signaling pathways. Here we examine how different members of the cadherin family act in different developmental contexts, and discuss the mechanisms involved.

Cadherins were originally identified as cell surface glycoproteins responsible for $\mathrm{Ca}^{2+}$-dependent homophilic cell-cell adhesion during morula compaction in the preimplantation mouse embryo and during chick development (Yoshida and Takeichi 1982; Gallin et al. 1983; Peyrieras et al. 1983). Subsequently, >100 family members have been identified with diverse protein structures, but all with characteristic extracellular cadherin repeats (ECs) (Nollet et al. 2000). Cadherins are important in both simple and complex organisms. In addition to vertebrates, insects, and nematodes, members of the cadherin family are found in unicellular choanoflagellates (King et al. 2003), the diploblast Hydra (Hobmayer et al. 2000), and the sponge Oscarella carmela (Nichols et al. 2006).

In the three decades since their discovery, it has become clear that the role of cadherins is not limited to mechanical adhesion between cells. Rather, cadherin function extends to multiple aspects of tissue morphogenesis, including cell recognition and sorting, boundary formation and maintenance, coordinated cell move-

[Keywords: Cadherin; protocadherin; embryogenesis; cell sorting; tissue differentiation]

${ }^{1}$ Corresponding author.

E-MAIL wjinelson@stanford.edu; FAX (650) 725-8021.

Article is online at http://www.genesdev.org/cgi/doi/10.1101/gad.1486806. ments, and the induction and maintenance of structural and functional cell and tissue polarity. Cadherins have been implicated in the formation and maintenance of diverse tissues and organs ranging from polarization of simple epithelia, to mechanically linking hair cells in the cochlea, to providing an adhesion code for neural circuit formation during wiring of the brain (Yagi and Takeichi 2000; Gumbiner 2005). Given the breadth of their functions, it is not surprising that defective cadherin expression has also been linked directly to a wide variety of diseases including the archetypal disruption of normal tissue architecture, metastatic cancer (Berx and Van Roy 2001).

The large size of the cadherin family and the structural diversity of its members may have evolved to enable the many types of cell interactions required for tissue morphogenesis in complex organisms. The number of cadherins as well as distinct features of their gene structure permit precise temporal and spatial transcriptional regulation of cadherin subtypes, and variations in protein structure, particularly the cytoplasmic domain, facilitate interactions that result in both specific modulation of cadherin activity and initiation of intracellular signaling cascades in response to adhesion.

In this review, we focus on the three types of cadherins and their roles in development: classical cadherins, protocadherins, and atypical cadherins involved in planar cell polarity (PCP). We examine the distributions and functions of cadherins in the formation and maintenance of tissues, and the mechanisms thought to be important in regulating cadherin activity. Note that our knowledge of each of these cadherin family subtypes is not equivalent, and by necessity we focus more on the classical cadherins, although this knowledge may provide a framework for understanding other subtypes in the future.

\section{Classical cadherins}

Classical cadherins were the first subtype of the cadherin family identified, and structure/function studies have provided detailed insights into their molecular regulation. Cadherins are expressed in almost all vertebrate tissues, form primarily homophilic cell-cell interactions, are often concentrated in the adherens junction 
$(\mathrm{AJ})$, and appear to modulate adhesion through dynamic interactions with the actin cytoskeleton.

\section{Regulation of cadherin expression and activity}

Structural and functional organization of the extracellular domain Classical cadherins, which are subdivided into type I and type II, have five ECs in the extracellular domain (Fig. 1). Type I classical cadherins mediate strong cell-cell adhesion and have a conserved HAV tripeptide motif in the most distal EC (EC1). They include epithelial $(\mathrm{E})$ and neuronal $(\mathrm{N})$ cadherin, among others. In contrast, type II classical cadherins, such as vascular epithelium (VE) cadherin, lack this motif. The EC1 domain is important for homophilic adhesion and contains conserved tryptophan residues that are responsible for trans-cadherin binding (Nose et al. 1988; Chen et al. 2005; Patel et al. 2006), although heterophilic interactions between classical cadherins have also been reported (Shimoyama et al. 2000; Niessen and Gumbiner 2002; Foty and Steinberg 2005). Other EC domains of individual family members specify interactions with other binding partners, which translates into unique functionality; for example, the EC4 domain of N-cadherin binds fibroblast growth factor receptor (FGFR) and activates downstream signaling by FGFR (Fig. 2; Williams et al. 2001).

Structural and functional organization of the cytoplasmic domain The cytoplasmic domain is highly conserved between different subtypes of classical cadherins and binds directly to several cytoplasmic proteins including $\beta$-catenin and p120 (Fig. 2). Cytoplasmic binding partners affect classical cadherin interactions with the actin cytoskeleton. p120 may regulate the cadherin-actin cytoskeleton nexus directly by binding and inhibiting RhoA (Anastasiadis and Reynolds 2001) and indirectly activating Rac1 and Cdc42 via Vav2 (Noren et al. 2000), while stabilizing cadherins at the cell surface (Davis et al. 2003). $\beta$-Catenin, which also functions as a cotranscriptional activator with the T-cell factor (TCF) family of transcription factors (Brembeck et al. 2006), binds directly to $\alpha$-catenin (Aberle et al. 1994), which in turn is an actin filament-binding/bundling protein that also interacts with other actin-binding proteins (Kobielak and Fuchs 2004).
These protein-protein linkages have lead to the conclusion that $\alpha$-catenin links cadherins to actin, even though most are based on binary interaction data. However, it was recently shown using a combination of direct binding studies with purified proteins and measurement of protein dynamics in live cells that $\alpha$-catenin does not interact with $\beta$-catenin and filamentous actin simultaneously (Drees et al. 2005; Yamada et al. 2005). Instead, $\alpha$-catenin behaves in an allosteric manner, dependent on the formation of either an $\alpha$-catenin monomer that binds strongly to $\beta$-catenin or a homodimer that binds strongly to actin (Drees et al. 2005). In addition to binding actin, $\alpha$-catenin homodimers inhibit binding of the actinnucleating Arp2/3 complex to actin filaments and thereby suppress actin polymerization (Drees et al. 2005). $\alpha$-Catenin also recruits formin-1, which acts to nucleate unbranched actin cables, to AJs (Kobielak et al. 2004). This may be important in regulating actin dynamics at cell-cell contacts. Cells form transient contacts mediated by cadherins present on highly dynamic lamellipodia extensions (Adams et al. 1998) that are driven by Arp2/3-mediated polymerization of branched actin networks (Pollard and Borisy 2003). As the contact matures, cadherins become concentrated between opposed cell surfaces, lamellipodial movements slow and eventually cease as a stable cell-cell contact is established (Ehrlich et al. 2002; Vaezi et al. 2002), and actin filaments adjacent to mature AJs become organized into unbranched bundles parallel to the membrane (Hirokawa et al. 1983). Thus, the suppression of Arp2/3-mediated lamellipodia activity, and the concomitant localization of formin-1 and formation of unbranched actin bundles at cell-cell contacts could be coordinated by $\alpha$-catenin.

Dynamic cell movements rely on actomyosin activity (Dawes-Hoang et al. 2005), and it has been assumed that this occurs at the level of the AJ (Wessells et al. 1971) and involves cadherins (Gates and Peifer 2005). If the cadherin-catenin complex does not interact directly with actin, what anchors actin in the $\mathrm{AJ}$ ? $\alpha$-Catenin binds several actin-binding proteins that could link the cadherincatenin complex to the actin cytoskeleton, although these have been shown as binary interactions and not in the molecular context of a complex with cadherin and actin (Weis and Nelson 2006). An additional candidate protein is Shroom, a PDZ domain-containing actin-binding protein required for neural tube morphogenesis that
Figure 1. Cadherin structure. All cadherins possess calcium-binding EC repeats of varying number. Nonclassical cadherins also have additional extracellular motifs including laminin and EGF domains and flamingo boxes. Cadherins are single membrane-spanning proteins with the exception of flamingo, which is a seven-pass membrane protein. The cytoplasmic tail of classical cadherins is conserved, but is different from that of protocadherins and atypical cadherins. Brackets indicate that protocadherins have either six or seven ECs. Note that the represented size of each domain is not to molecular scale.

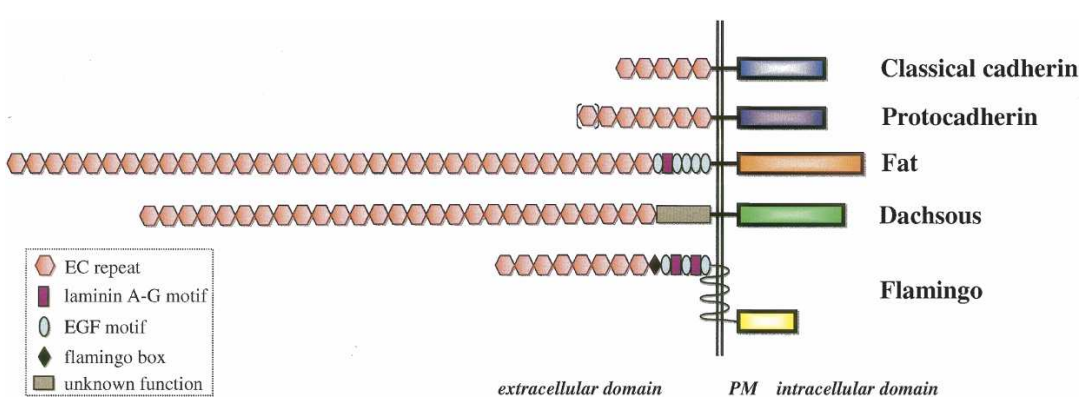




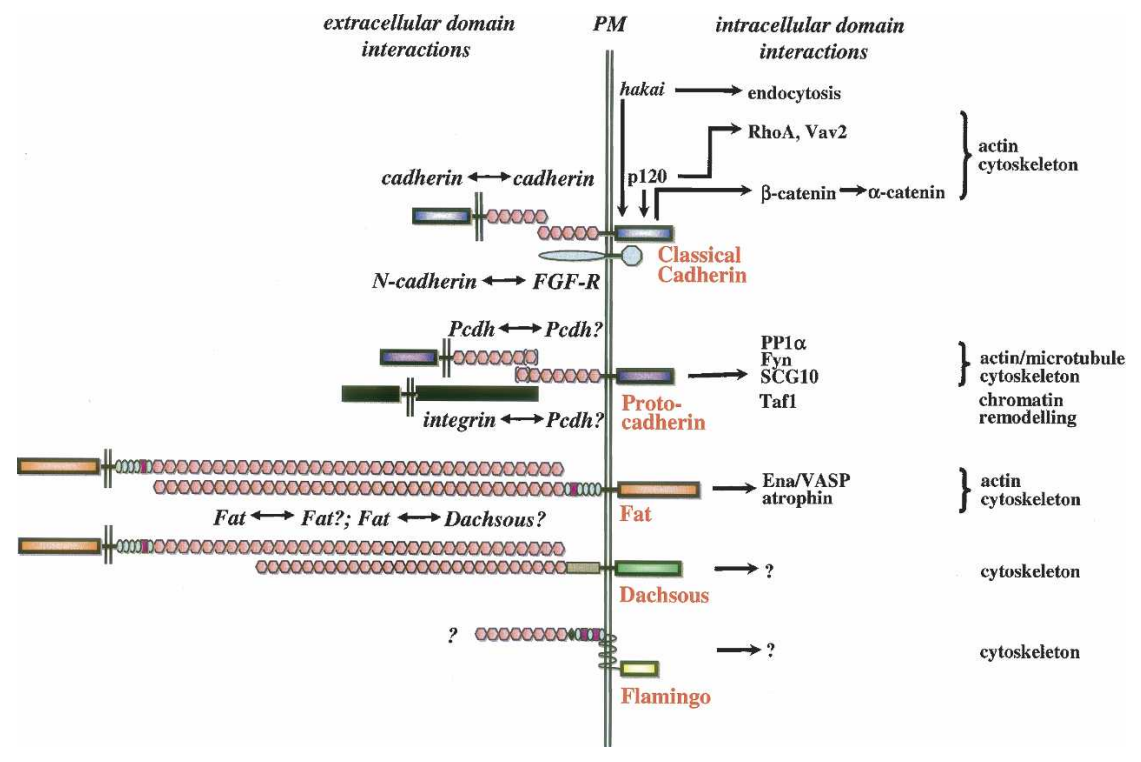

Figure 2. Cadherin-binding partners. In addition to extracellular homophilic (and some heterophilic) trans binding, classical cadherins interact intracellularly with the catenins p120 and Hakai, which regulate the actin cytoskeleton and cadherin endocytosis. N-cadherin also binds FGFR. Protocadherins exhibit weak homophilic adhesion. The cytoplasmic domains of protocadherins bind phosphatases, microtubuledestabilizing proteins, and chromatin remodeling factors. Pcdh- $\alpha$ s also interacts with the Fyn tyrosine kinase, Reelin receptor, and integrins in vitro. The cytoplasmic domain of Fat interacts directly with Atrophin transcriptional corepressors and members of the Ena/Vasp family of actin regulators. The extracellular domain of Fat may form homophilic adhesions, or heterophilic adhesions with Ds. Ds and Fmi may be linked to the cytoskeleton. Interactions that have not been shown definitively in vivo are indicated with a question mark. Brackets indicate that protocadherins have either six or seven ECs. Note that the represented size of each domain is not to molecular scale. localizes to AJs (Hildebrand 2005). Another is Vezatin, an AJ transmembrane protein that may link myosin to the cadherin-catenin complex (Kussel-Andermann et al. 2000). Also, a recent report identified an interaction between the synaptotagmin-like protein Bitesize (Btsz) and Moesin, an actin-binding member of the Ezrin-RadixinMoesin (ERM) family of cytoskeletal proteins; significantly, Btsz mutants fail to establish proper actin organization at AJs during Drosophila cellularization (Pilot et al. 2006). Further studies are required to investigate how the cadherin-catenin complex is functionally linked to these modifiers at the actin cytoskeleton.

Regulation of cadherin expression Classical cadherin expression is regulated at many levels including gene expression and transport to, and protein turnover at the cell surface (Fig. 3).

Cadherin transcription is directly regulated by methylation and repression of promoter activity (Fig. 3). Methylation is a common modification of DNA mediated by a family of DNA methyltransferase enzymes that catalyze the addition of a methyl group to cytosine residues at CpG dinucleotides (Richards 2006). During carcinogenesis, methylation of the E-cadherin promoter is associated with reduced E-cadherin expression, and with disease progression and metastasis (Strathdee 2002). Several classical cadherin genes also possess an unusually large second intron (in humans, the size of intron 2 compared to total gene size for E-cadherin and $\mathrm{N}$-cadherin are $63 \mathrm{~kb}$ to $98 \mathrm{~kb}$ and $134 \mathrm{~kb}$ to $245 \mathrm{~kb}$, respectively), which has been shown for E-cadherin to contain regulatory elements that modulate overall cadherin levels and tissuespecific expression during development (Stemmler et al. 2005). Zinc finger proteins of the Slug/Snail family and
Smad-Interacting Protein (SIP1) are repressors of E-cadherin gene transcription (Cano et al. 1996; Batlle et al. 2000; Comijn et al. 2001; Conacci-Sorrell et al. 2003). Decreased E-cadherin gene transcription results in a loss of cell-cell adhesion and increased cell migration (Thiery 2002), as well as accumulation of cytoplasmic, signalingcompetent $\beta$-catenin that may function independently of, or synergize with Wnt signaling (Ciruna and Rossant 2001). Slug may be a target gene of the TCF/ $\beta$-catenin complex (Conacci-Sorrell et al. 2003) that also binds to and represses the E-cadherin promoter (Jamora et al. 2003). Thus, repression of cadherin expression by Slug/ Snail/SIP1 or TCF/ $\beta$-catenin complex may not only reduce cell-cell adhesion, but the concomitant increase in cytoplasmic $\beta$-catenin may lower the activation threshold of the Wnt pathway.

Transport of newly synthesized E-cadherin to the plasma membrane requires binding of $\beta$-catenin /Chen et al. 1999), and once delivered to the cell surface E-cadherin is regulated by phosphorylation, ubiquitination, and proteolysis (Fig. 3). The structural integrity of the cadherin/catenin complex is positively and negatively regulated by phosphorylation. Three serine residues in the E-cadherin cytoplasmic domain (S684, S686, S692) are phosphorylated by Casein Kinase-II (CKII) and glycogen synthase kinase-3 $\beta$ (GSK3 $\beta$ ), which generates additional interactions with $\beta$-catenin resulting in a large increase in affinity between the two proteins (Huber and Weis 2001). In contrast, tyrosine phosphorylation of $\beta$-catenin at Y489 or Y654 disrupts binding to E-cadherin, and at Y142 binding to $\alpha$-catenin; tyrosine phosphorylation of $\beta$-catenin is balanced by protein tyrosine phosphatases that stabilize $\beta$-catenin-E-cadherin interactions (Lilien and Balsamo 2005). 


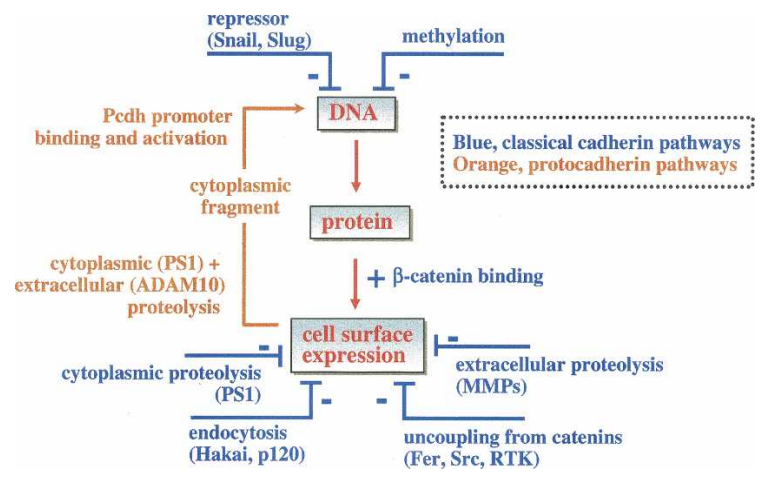

Figure 3. Regulation of cadherins. Classical cadherins (blue scheme) are transcriptionally regulated by zinc-finger transcription factors such as Snail and Slug, and promoter methylation. Exocytosis of newly synthesized protein from the endoplasmic reticulum to the cell surface is dependent on binding to $\beta$-catenin. Cadherin levels at the cell surface are regulated by endocytosis upon Hakai-mediated ubiquitination subsequent to uncoupling from catenins following phosphorylation; cadherin can be cleaved by ADAM10, MMPs, or PS1. Protocadherins (orange scheme) at the plasma membrane can be sequentially cleaved by ADAM10 and PS1. In the case of Pcdh- $\gamma$, the resulting fragment localizes to the nucleus and can activate transcription of the Pcdh- $\gamma$ gene cluster.

Cadherin-mediated cell-cell adhesion is modulated by changes in the level of cadherin on the cell surface (Duguay et al. 2003; Foty and Steinberg 2005). Cadherins are targets of ADAM (a disintegrin and metalloprotease domain) 10 (Maretzky et al. 2005; Reiss et al. 2005) that cleaves the cadherin extracellular domain close to the transmembrane domain (Fig. 3). The resulting extracellular fragment could further disrupt adhesion by competing with trans interactions between full-length cadherin complexes (Wheelock et al. 1987). The cytoplasmic domain of classical cadherins is also the target for proteolytic cleavage by the $\gamma$-secretase activity of Presenilin-1 (PS1), which results in a loss of cell-cell adhesion (Fig. 3; Marambaud et al. 2002); it has also been reported that the released cytoplasmic fragment binds the cAMP response element-binding protein (CREB)-binding protein (CBP), a scaffold for activating transcriptional modulators of the CREB basal transcription complex, and targets it for degradation (Marambaud et al. 2003). E-cadherin is actively endocytosed via clathrin-coated vesicles (Bryant and Stow 2004), which can result in rapid loss of cell-cell adhesion. It is targeted for internalization following ubiquitination by the E3 ubiquitin ligase Hakai (Figs. 2, 3; Fuiita et al. 2002) and other pathways that involve disruption of the cadherin-catenin complex by tyrosine kinases (Kamei et al. 1999; Avizienyte et al. 2002). Cadherin stability at the cell surface is also regulated by p120 as loss of cadherin-p120 binding results in rapid endocytosis of the E-cadherin complex (Fig. 3; Davis et al. 2003).

The extensive transcriptional and post-transcriptional regulation of cadherins suggests that the level of cadherin cell surface expression and the maintenance of linkage to intracellular binding partners (controlled per- haps by additional signaling cascades) modify cadherin activity. This is further supported by experiments in fibroblasts expressing different cadherins that show sorting out of mixed cell populations is mediated by surface expression levels of cadherins (Duguay et al. 2003; Foty and Steinberg 2005). Thus, it appears that cell sorting can be mediated by differences in levels of cadherin cell surface expression as well as subtype (see below). Recently, validation of these regulatory mechanisms within the developmental context of tissue morphogenesis has been established in Drosophila. In the fly eye, requirement of asymmetrical localization of Drosophila neuronal (DN)cadherin for proper cone cell morphology has been shown (Hayashi and Carthew 2004). Intriguingly, regulated endocytosis and recycling of cadherins controlled by PCP components appears to be necessary for hexagonal wing cell packing (Classen et al. 2005). These results demonstrate in vivo two distinct mechanisms to facilitate cell sorting by regulating the level and localization of cadherin surface expression.

\section{Cadherin expression and function in development}

Classical cadherins in cell sorting Each subtype of classical cadherin tends to be expressed at the highest levels in distinct tissue types during development. For example, in addition to being present at the morula stage of embryogenesis, E-cadherin is expressed in all epithelia and is important for establishing and maintaining apicobasal polarity (Fig. 4E); N-cadherin is expressed in neural tissue and muscle; R-cadherin is expressed in the forebrain and bone; P-cadherin is present in the basal layer of the epidermis; and, VE-cadherin is expressed in endothelial cells (for details of cadherin subtype expression patterns see Takeichi 1988; Hirano et al. 2003). Other classical cadherins such as Cadherin- 6 and Cadherin- 11 are expressed preferentially in the kidney and mesoderm, respectively (Nollet et al. 2000). However, it is also clear that there is overlap in the tissue distributions of classical cadherins such that E-cadherin, for example, is expressed in the nervous system (Takeichi 1988).

These tissue expression patterns of cadherin subtypes, in conjunction with their homophilic adhesive properties, may facilitate sorting of specific cell types into tissues. The role of cadherin subtypes in mediating cell sorting has been shown in tissue culture using nonadherent fibroblasts exogenously expressing different cadherins (Fig. 4A,B; Nose et al. 1988; Foty and Steinberg 2005). Cadherin-mediated cell sorting was shown to be physiologically relevant in Drosophila oogenesis when the oocyte is localized to the posterior of the germline cyst by homophilic interactions between the Drosophila functional homolog of E-cadherin, DE-cadherin, expressed by both the oocyte and posterior follicle cells (Godt and Tepass 1998). It has subsequently been observed in a variety of developmental contexts including Xenopus gastrulation and vertebrate limb formation (Gumbiner 2005). Other studies have also emphasized the importance of homophilic adhesion of cadherins in cell sorting. Overexpression of Cadherin-6B or Cad- 


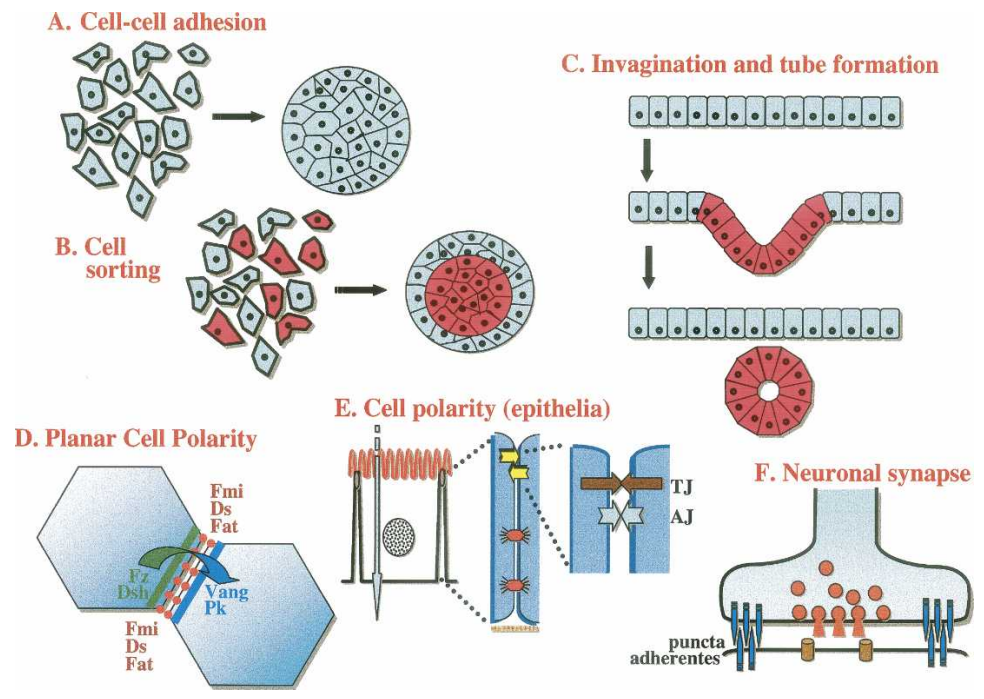

Figure 4. Developmental roles of cadherins. $(A)$ Cadherins mediate $\mathrm{Ca}^{2+}$-dependent cell-cell adhesion. $(B)$ Differential expression of cadherins (either by modulating subtype or expression level) induces sorting out of mixed cell populations. $(C)$ Cadherin subtype switching occurs during coordinated cell movements such as neurulation, where the invaginating neural plate expresses $\mathrm{N}$-cadherin, while the overlying ectoderm expresses Ecadherin. (D) Cadherins function in PCP. Ds and Fat interact directly and are upstream of $\mathrm{Fz}$, while Fmi functions downstream, leading to additional expression of PCP components and asymmetrical localization of proteins including $\mathrm{Fz}$, Disheveled (Dsh), Van Gogh (Vang), and Prickle (Pk) (Klein and Mlodzik 2005). Classical cadherins have specialized distributions at the AJ (light-blue arrows) of polarized epithelia $(E)$, and at puncta adherentes (blue arrows) that surround the active zone at the neuronal synapse $(F)$. (TJ) Tight junction; (AJ) adherens junction. herin-7 in Purkinje cell progenitors resulted in their preferential redistribution to regions of the cerebellum that express the respective cadherin endogenously (Luo et al. 2004). In the mouse telencephalon, a compartment boundary is established between the primordia of the cerebral cortex and the striatum comprising complementary expression patterns of R-cadherin and Cadherin-6. Expression of either exogenous Cadherin- 6 or R-cadherin in cells located in the vicinity of the boundary induced strong preferential sorting of cells across the presumptive boundary into the Cadherin-6 or R-cadherin positive compartment, respectively (Inoue et al. 2001). It has also been postulated that expression of $\mathrm{N}$-cadherin in tumor cells acts as a targeting mechanism for endothelial and stromal tissue during metastasis (Hazan et al. 2000; De Wever et al. 2004; Qi et al. 2005).

Studies of cell sorting in the lumbar spinal cord of chick embryos has provided further insights into the roles of different cadherins and the importance of the EC1 domain. Differences in the distributions of six cadherins in the lateral motor column occur concurrently with the segregation of neurons into different motor pools. Misexpression of one of these cadherins, MN-cadherin, but not another (Cadherin-6B), resulted in incorrect mixing of motor pools (Price et al. 2002). This indicates that the expression and homophilic adhesion of MN-cadherin-expressing cells controls the formation of discrete neuronal clusters in the lateral motor column. Significantly, replacing the EC1 domain of Cadherin-6B with that of MN-cadherin was sufficient to confer on Cadherin-6B the ability to (mis-) sort neurons into motor pools similar to misexpressing MN-cadherin (Price et al. 2002; Patel et al. 2006). This result provides physiologically relevant evidence that the EC1 domain is a critical determinant of the specificity of cadherin adhesion in cell sorting.

Although specificity of adhesion by EC1 provides one mechanism to explain how cells segregate from each other within complex cell mixtures, an explanation of tissue development induced by different cadherins ex- pressed in embryonic stem cells (ESCs) is not as straightforward. Larue et al. (1996) showed that ESCs isolated from E-cadherin ${ }^{-/-}$preimplantation embryos failed to differentiate into any organized structure when induced to form teratomas in mice; in contrast, ESCs from E-cadherin $^{+/-}$or wild-type embryos formed many different tissues. Strikingly, E-cadherin ${ }^{-/-}$ESCs expressing E-cadherin or $\mathrm{N}$-cadherin transgenes formed teratomas with either epithelial or neuroepithelial structures, respectively (Larue et al. 1996); rescue with Cadherin-11 yielded teratomas with bone and cartilaginous structures (Kii et al. 2004). These results imply that individual cadherin subtypes instruct the differentiation of specific tissues, and perhaps suppress the differentiation of others. The mechanisms involved are unknown. For example, it is unclear whether the effect could be due to differences in adhesion strength or cell sorting mediated by the extracellular domain of each cadherin transgene. That each cadherin might activate tissue-specific intracellular signaling pathways seems to be at variance with the high sequence similarity and conserved binding partners of the cytoplasmic domain of all of these cadherins (see above). However, differential activation via the extracellular domain would not be unprecedented, considering the subtype-specific binding of N-cadherin to FGFR and subsequent downstream signaling (Williams et al. 1994). In this context it is interesting to note that studies of Xenopus trunk mesoderm patterning found that while disruption of cell-cell adhesion results in tissue disorganization, modulation of $\beta$-catenin activity was responsible for cell sorting at the individual cell level (Reintsch et al. 2005).

Cadherin subtype switching in development Subtype switching is a prominent physiological feature of cadherin morphogenetic function during development. The first of these occurs during gastrulation and results in a change in cadherin expression from DE-cadherin to DNcadherin in the developing Drosophila mesoderm /Oda et al. 1998). A similar conversion from E-cadherin to N- 
cadherin is observed during neurulation in chick embryos (Fig. 4C; Hatta et al. 1987). In both cases, the previously well-ordered tissue type acquires (D)N-cadherin expression prior to a major morphological movement. Cells lose their epithelial morphology, convert to a fibroblastic shape, and acquire the ability to delaminate from the tissue and migrate, a process known as epithelial-mesenchymal transition (EMT).

EMT is best-studied in the context of tumor progression (Maeda et al. 2005). As the pathological and embryonic processes involved in EMT are similar, results obtained from studies of tumor progression can give insight into the mechanisms of EMT in developmental contexts. During tumor progression, E-cadherin or Cadherin-13 (also known as H-cadherin or T-cadherin) are down-regulated, and concomitantly the expression of N-cadherin, R-cadherin, Cadherin- 6 , or Cadherin-11 is increased (Islam et al. 1996; Shimazui et al. 1996; Johnson et al. 2004). These switches in cadherin expression are associated with increased invasion and poor prognosis (Paul et al. 1997). Interestingly, breast cancer cells forced to express both E-cadherin and $\mathrm{N}$-cadherin are as invasive as those expressing $\mathrm{N}$-cadherin alone, suggesting that differential adhesive properties between cadherins are not sufficient to mediate the change in motility (Nieman et al. 1999). N-cadherin binds directly to, and activates FGFR (Fig. 2; Williams et al. 1994), leading to mitogenactivated protein kinase-extracellular signal-regulated kinase (MAPK-ERK) signaling and metalloproteinase (MMP) induction (Suyama et al. 2002). MMP-3 cleaves the extracellular domain of E-cadherin, providing a potential mechanism for functional inactivation of E-cadherin upon N-cadherin expression (Xian et al. 2005).

Roles of classical cadherins in dynamic cell movements Tissues expressing E-cadherin also undergo cell morphogenetic movements involving convergence and extension through radial and mediolateral intercalation during epiboly and gastrulation, respectively. When E-cadherin adhesion is disrupted during Zebrafish epiboly, epiblasts still intercalate but are not stabilized in the external layer and often deintercalate (Kane et al. 2005; Shimizu et al. 2005). Intercalation during gastrulation involves remodeling of AJs to expand cell-cell adhesions in one plane of the epithelium and contract them in the perpendicular plane (Bertet et al. 2004). This process is thought to require interactions between actin filaments, Myosin II, and the AJ like those that occur during apical constriction in cell morphogenesis (Dawes-Hoang et al. 2005), although it is not clear how actomyosin is directly anchored to the AJ (see above).

Classical cadherins in orientation of the plane of cell division Analysis of the roles of cadherins in spreading and intercalation revealed that E-cadherin can also specify the plane of cell division. Regulating cell division along one axis permits directional expansion of tissues (Lu et al. 2001; Wang et al. 2004). Cadherins appear to regulate the plane of cell division in several cellular contexts. In the Drosophila testis, germ stem cell (GSC) mi- tosis gives rise to a stem cell and a gonialblast. Maintenance of the GSC population requires the proper orientation of the division plane, which is determined by cadherin-dependent adhesion between GSCs and the "hub," a cluster of somatic cells (Yamashita et al. 2003). Cadherin-mediated cell adhesion may also be important in polarized division of mammalian hematopoietic stem cells (HSCs) as N-cadherin localizes asymmetrically between long-term HSCs and spindle-shaped osteoblast cells (Zhang et al. 2003). Another example is the role of the $\mathrm{AJ}$ in the regulation of neuroblast delamination from the neuroectoderm in Drosophila development (Wodarz 2005). The neuroblast retains contacts with the neuroectoderm through the AJ, which positions important polarity cues to the apical domain, while determinants of the ganglion mother cell fate are located in the basal domain of the dividing cell.

Classical cadherins in organization and function of the nervous system The development and maintenance of the nervous system are major areas of focus in the study of classical cadherins, as (1) different cadherins are expressed in different cells and regions of the nervous system, (2) dynamic cadherin adhesion is important in neurite outgrowth and guidance and synapse formation, and (3) cadherins can regulate synaptic plasticity.

Specific classical cadherins localize to different regions of the embryonic brain and peripheral nervous system (Hirano et al. 2003), and disruption of cadherin expression results in cell mixing at domain boundaries (Stoykova et al. 1997; Inoue et al. 2001). Although there is no obvious functional correlation between neurons within a particular region and the cadherins expressed in that region, as development proceeds several cadherins become restricted to specific circuits within the CNS (Suzuki et al. 1997). In other cases, multiple cadherins are expressed in one brain region that receives information from (Arndt et al. 1998; Redies et al. 2000) or sends information to several neuronal structures (Redies et al. 1993; Wohrn et al. 1999), suggesting in this case a role for cadherins in the control of cell-cell networks involved in the transmission of different signals.

Cadherins facilitate circuit formation during growth cone navigation and path-finding by controlling axon fasciculation and targeting. Neuronal classical cadherins are expressed in distinct axonal tracts in Drosophila and the chick embryo, and loss of function results in disrupted fasciculation (Iwai et al. 1997; Honig et al. 1998). In addition, $\mathrm{N}$-cadherin and $\mathrm{R}$-cadherin expression stimulates neurite outgrowth at least partially by activating FGFR (see above) (Redies et al. 1992; Riehl et al. 1996), while Cadherin-11 promotes axon elongation (Marthiens et al. 2005) and Cadherin-13 acts as a repellant cue for growth cones (Fredette et al. 1996). There is some evidence that cadherins also function as axonal targets in both the chick and Drosophila /disruption of $\mathrm{N}$-cadherin adhesion results in mistargeting of axons in the visual systems of both organisms [Inoue and Sanes 1997; Lee et al. 2001]), but a widespread function of cadherins in targeting has not been established definitively 
as the target brain region and growing axon often do not express the same cadherin (Shimamura et al. 1992), and fiber projection is normal in Cadherin-11-deficient mice (Manabe et al. 2000). However, recent work has implicated $\mathrm{N}$-cadherin-mediated adhesion in neurogenesis following injury (Chen et al. 2006), indicating that more work is required to define the role of cadherins in circuit formation.

There is increasing evidence for a role of classical cadherins in the formation of individual synapses. N-cadherin is one of the first proteins to localize to most nascent synapses (Fannon and Colman 1996; Uchida et al. 1996; Benson and Tanaka 1998), and a synaptic localization of other cadherins, including R-cadherin and Cadherin-7, has been found (Heyers et al. 2004). As development proceeds, $\mathrm{N}$-cadherin becomes restricted to excitatory terminals (Benson and Tanaka 1998), raising the possibility that expression of specific cadherin subtypes might be instructive in synapse function. Interestingly, loss of $\mathrm{N}$-cadherin in mice has no effect on the initiation of neurulation, although malformations of the neural tube occur (Radice et al. 1997), and blocking N-cadherin function with dominant-negative constructs does not result in neurite outgrowth abnormalities, but leads to altered dendritic spine morphology and synapse density concomitant with a loss of $\beta$-catenin from spines (Togashi et al. 2002). A similar phenotype is observed when neuronal-specific $\alpha \mathrm{N}$-catenin is deleted, suggesting cadherins may affect spine morphology through regulation of the actin cytoskeleton (Abe et al. 2004). At mature synapses, cadherins form junctions (puncta adherentes) that surround the active zone from which neurotransmitter release occurs (Fig. 4F; Fannon and Colman 1996; Uchida et al. 1996).

Although cadherins may play only a structural role at synapses, they have been implicated in neuronal function through regulation of synaptic plasticity. Depolarization of excitatory neurons results in increased N-cadherin-mediated adhesion (Tanaka et al. 2000), as does stimulation designed to induce long-term potentiation (LTP) (Bozdagi et al. 2000). Intriguingly, LTP can be blocked with antibodies against the extracellular domain of N-cadherin or E-cadherin, neither of which effect normal synaptic function (Tang et al. 1998). Reduced Cadherin-11 levels have also been reported to stimulate LTP (Manabe et al. 2000). Whether these effects are due to cadherin-mediated changes in the distance between preand post-synaptic terminals or the width of synapses is not well understood.

A possible mechanism for $\mathrm{N}$-cadherin-mediated plasticity is suggested by experiments showing that the cytoplasmic tail of $\mathrm{N}$-cadherin is cleaved sequentially by ADAM10 and the $\gamma$-secretase activity of PS1 in response to N-methyl-D-aspartate receptor (NMDA) stimulation, and that the released cytoplasmic fragment localizes to the nucleus where it may function to alter gene transcription necessary for LTP (Uemura et al. 2006a,b). The juxta-membrane domain of $\mathrm{N}$-cadherin has also been shown to be important in regulating voltage-gated calcium currents in chick ciliary neurons (Piccoli et al.
2004), although the mechanism is unknown. Most recently, evidence for $\mathrm{N}$-cadherin function in short-term plasticity in glutamatergic neurons was reported (Jungling et al. 2006).

In summary, classical cadherins play key morphogenetic roles in diverse tissues throughout development by mediating cell interactions necessary for cell sorting, coordinated cell movements, planar cell division, and formation and maintenance of boundaries in tissues. Studies performed mostly in tissue culture cells have shown that cadherin expression is regulated at the transcriptional level, and at the cell surface through complex and dynamic interactions with the actin cytoskeleton and signaling pathways. Although studies in vivo indicate that these control points are also important in more complex cellular contexts, further work is required to establish the significance of these regulatory pathways for cadherin function in tissue morphogenesis.

\section{Protocadherins}

Protocadherins are a class of cadherins that are primarily expressed in the nervous system, but have additional important developmental expression patterns in nonneuronal tissues (Sano et al. 1993). With $>60$ members identified to date, they make up the largest subfamily of cadherins (Wu and Maniatis 1999). Interestingly, they are present in vertebrates and certain sea sponges with epithelial structures, but homologs have not been found in Drosophila or Caenorhabditis elegans (Nichols et al. 2006). Work on understanding protocadherin functions is still in its infancy compared with classical cadherins, but there is tantalizing evidence of roles in tissue development and a variety of cell functions.

\section{Structural organization of protocadherins}

Protein structure Like classical cadherins, protocadherins are type I transmembrane proteins. However, their extracellular domain has six to seven EC repeats that lack the conserved sequence elements present in classical cadherins (Fig. 1; Junghans et al. 2005). In general, protocadherins have weak adhesive properties in cell aggregation assays, and it is unclear whether they mediate homophilic or heterophilic adhesions (Chen and Gumbiner 2006). In addition, the cytoplasmic domain of protocadherins is structurally diverse, in contrast to the homology between classical cadherins, and less is known about cytoplasmic binding partners (see Fig. 4; see below). It is likely that the majority of protocadherin intracellular domains have the capacity for novel interactions and functions that are just beginning to be elucidated.

Gene structure The majority of protocadherins can be classified into three clusters $(P c d h-\alpha, P c d h-\beta$, and $P c d h$ $\gamma)$ each with unique gene structures that encode constant and variable domains. Each of the $\alpha$-protocadherin and $\gamma$-protocadherin clusters consists of three constant exons 
coding for a portion of the cytoplasmic domain of the entire group preceded by a tandem array of individual variable exons encoding the rest of the cytoplasmic domain and the extracellular and transmembrane domains of each protocadherin; $\beta$-protocadherins do not have constant exons, but are transcribed from a cluster of single exon genes (Wu and Maniatis 1999). The similarity between protocadherin and immunoglobulin gene structure raised the possibility that clustered protocadherins undergo DNA rearrangements similar to that of immunoglobulin genes (Wu and Maniatis 1999). However, this does not appear to be the case. Instead, expression of each protocadherin variable exon is controlled by its own promoter (Wu et al. 2001), some of which can be activated by a cleaved cytoplasmic fragment of the cognate protein (Fig. 3). This may represent a positive feedback mechanism to reinforce expression of specific protocadherins within individual cells (Hambsch et al. 2005). There are also multiple splice variants of individual transcripts, indicating the potential for great protein diversity (Sano et al. 1993; Sugino et al. 2000). Additional unclustered protocadherins have been identified including paraxial protocadherin (PAPC), axial protocadherin (AXPC) (Yamamoto et al. 1998; Kuroda et al. 2002), and neural fold protocadherin (NFPC) (Bradley et al. 1998) in Xenopus, and $\delta$-protocadherins in vertebrates (Redies et al. 2005; Vanhalst et al. 2005).

\section{Protocadherin function in cell organization in development}

Protocadherins in development Functions of protocadherins have been examined in a variety of developmental systems. During Xenopus gastrulation, PAPC is necessary for separation of ectoderm and mesoderm, and this requires interaction of PAPC with Frizzled-7 and induction of downstream GTPase signaling through the PAPC intracellular domain (Medina et al. 2004; Unterseher et al. 2004). PAPC is expressed in a complementary pattern to AXPC, and this pattern is important for boundary formation and sorting of cells into the paraxial (PAPC) and axial (AXPC) mesoderm that form the somites and notochord, respectively (Yamamoto et al. 1998; Kuroda et al. 2002). Cell sorting appears to require the extracellular domain of both proteins and involves regulation of convergence and extension movements (Kim et al. 1998). However, PAPC does not mediate cell-cell adhesion directly, but seems to function in cell sorting by modulating C-cadherin adhesion through an unknown mechanism (Chen and Gumbiner 2006). The conservation of these mechanisms in mammals is not currently established, as the putative mammalian PAPC homolog, Pcdh8, while expressed in the primitive streak, paraxial mesoderm, somites, and CNS, does not have a loss-offunction phenotype (Yamamoto et al. 2000). However, Pcdh8 may not represent the true PAPC homolog, as sequence identity is relatively low $(41 \%)$ (Frank and Kemler 2002).

Other protocadherins have roles in development and tissue morphogenesis. Protocadherin-10 (Pcdh10 or OL- protocadherin), although primarily expressed in the nervous system, is also present in somites and facilitates their segregation (Hirano et al. 1999; Murakami et al. 2006). NFPC is expressed in ectodermal cells of the neural fold in Xenopus (Bradley et al. 1998) and disruption of NFPC inhibits neural tube closure and results in disorganization of epithelial cells within the folds (Rashid et al. 2006). NFPC also mediates adhesion within the ectoderm, and expression of dominant negative NFPC causes blistering that can be rescued with C-cadherin, but not $\mathrm{N}$-cadherin or E-cadherin (Bradley et al. 1998). This may be due to differential adhesive properties of the rescue constructs or loss of a specific signaling function of NFPC.

While the importance of protocadherin function in gastrulation and somitogenesis has been shown, their expression in the nervous system in combination with their diversity and unusual gene structure has led to speculation that protocadherins are involved in wiring of neuronal circuitry; that is, each individual neuronal circuit, or set of functionally connected neurons, possesses a fingerprint of protocadherins that in addition to distinguishing it from every other circuit is required to initiate the appropriate connections within the developing nervous system. At present, evidence supporting this idea is mixed. On the positive side, protocadherins are present during embryogenesis and gradually become enriched at synapses (Kohmura et al. 1998), and the expression of $P c d h-\alpha$ genes decreases after neurons mature and become myelinated (Morishita et al. 2004). Also, Pcdh- $\alpha$ and Pcdh- $\gamma$ localize to the post-synaptic density and have been reported to interact with each other (Murata et al. 2004). Most significantly, in the mouse olfactory bulb and cerebellum, different neurons express different sets of Pcdh- $\alpha$ (Kohmura et al. 1998) and Pcdh- $\gamma$ isoforms (Wang et al. 2002a), respectively. On the negative side, even though multiple Pcdh- $\alpha$ transcripts are expressed by individual Purkinje neurons and their expression is consistently monoallelic (Esumi et al. 2005), there is no obvious correlation between protocadherin expression and neuronal function (Frank and Kemler 2002). Furthermore, deletion of the entire cluster of Pcdh- $\gamma$ genes in mice resulted in no general defects in neuronal survival, migration, or pathfinding, although there was loss of some spinal interneurons due to apoptosis, and spinal synaptic density was reduced (Wang et al. 2002b). The lack of general effects of Pcdh- $\gamma$ deficiency on the nervous system might be due to compensation by Pcdh- $\alpha$ and/or Pcdh- $\beta$ proteins. However, the localized effects of deletion of $P c d h-\gamma$ on interneurons of the spinal cord also indicate that expression of different members of the protocadherin family might specify both the survival and synaptic organization of different neuronal populations.

Protocadherin function in cell signaling Although protocadherin expression within the nervous system is well established, the molecular mechanism underlying their function is not currently known. The majority of protocadherins exhibit weak homophilic adhesion in aggregation assays (Chen and Gumbiner 2006). However, pro- 
tocadherin cell-cell adhesion can be strengthened if the cytoplasmic tail is replaced with that of E-cadherin (Obata et al. 1995), suggesting that the extracellular domain of protocadherins is able to form trans interactions, but the cytoplasmic domain does not efficiently stabilize those interactions to facilitate adhesion. Instead, the primary function of protocadherins may be to relay a signal to the cytoplasm in response to cell recognition, and not to maintain physical interactions between cells (Frank and Kemler 2002).

Protocadherins interact with a variety of proteins that could propagate intracellular signals. Pcdh- $\alpha$ proteins in mice have a RGD motif that can facilitate interactions with integrins in vitro (Fig. 2; Mutoh et al. 2004). Pcdh- $\alpha$ isoforms also interact with neurofilaments and the actin-bundling protein Fascin, depending on which constant exon codes for their intracellular domain (TrianaBaltzer and Blank 2006); the cytoplasmic protein Fyn, which has been implicated in higher brain functions such as LTP, memory, and spatial learning (Kohmura et al. 1998); and receptors for Reelin, which is involved in cortical organization and may act with Pcdh- $\alpha$ s to terminate neuroblast migration (Senzaki et al. 1999). Taf1, which functions in chromatin remodeling, interacts with NFPC and loss of Taf1 phenocopies knockdown of NFPC (Heggem and Bradley 2003), raising the possibility that NFPC engagement may alter gene transcription. Finally, protocadherin functions can be mediated by proteolysis. Pcdh- $\gamma$ proteins are cleaved specifically and sequentially by ADAM10 and PS1 (Marambaud et al. 2002; Haas et al. 2005). In addition to modulating adhesion (Reiss et al. 2006), proteolysis of Pcdh- $\gamma$ generates a cytoplasmic fragment that localizes to the nucleus and activates transcription of $P c d h-\gamma$ genes (Fig. 3; Hambsch et al. 2005). However, it appears to activate the promoter of every isoform, so specificity at the level of individual cells must be generated by another mechanism.

In summary, protocadherins play critical roles during embryogenesis, particularly within the CNS. It is clear that these functions frequently require activation of intracellular signaling in response to engagement of cellcell interactions. In combination with their potential for great protein diversity, this differential signaling capability suggests a powerful mechanism for highly specific responses to the initiation of cell-cell adhesion, but elucidation of the molecular details will require further study.

\section{Atypical cadherins and PCP}

PCP refers to polarized orientation of epithelial cells along the axis of the cell monolayer. This level of tissue organization was originally characterized in Drosophila in screens for mutants that affected the polarity of wing hairs, leg bristles, and photoreceptor omatidia (Fanto and McNeill 2004). Recent studies of PCP in vertebrates suggest that during development conserved components of this pathway coordinate global spatial cues with cell movement and orientation to achieve appropriate tissue morphogenesis. A core component of the signaling path- way that sets up PCP is the seven-membrane-spanning receptor frizzled (Fz) (Klein and Mlodzik 2005). Fz is localized asymmetrically in cells (Fig. 4D), and it is now clear that atypical members of the cadherin family play critical roles in regulating $\mathrm{Fz}$ localization and hence PCP signaling.

\section{Structure and interactions of atypical cadherins}

The large, atypical cadherins Dachsous (Ds), Fat, and Flamingo (Fmi) are involved in PCP signaling (Fig. 4D). Instead of five extracellular ECs characteristic of classical cadherins, Ds and Fat have 27 and 34 ECs, respectively (Mahoney et al. 1991; Clark et al. 1995). Fmi is unique amongst the cadherins, as it is the only member with a seven-pass, rather than a single, transmembrane domain and has a large extracellular sequence that includes nine ECs (Fig. 1; Nakayama et al. 1998). The cytoplasmic domains of Ds and Fat have sequence homology with the $\beta$-catenin-binding site of classical cadherins (Mahoney et al. 1991; Clark et al. 1995), although there is no evidence that either binds $\beta$-catenin; in mammalian tissue culture cells, Fat and the classical cadherin-catenin complex have nonoverlapping distributions (Tanoue and Takeichi 2004). Instead, mammalian Fat1 binds to Ena/VASP, a family of proteins that regulate actin cytoskeleton assembly and dynamics (Fig. 2; Moeller et al. 2004; Tanoue and Takeichi 2004).

Fmi, Ds, and Fat interact at several structural and functional levels. In Drosophila, Fmi functions downstream from $\mathrm{Fz}$ (Fig. 4D). Its expression precedes morphological changes associated with PCP, and Fmi localizes asymmetrically within those tissues (Usui et al. 1999). Although Fmi homophilic adhesion has been demonstrated in vitro, its role in PCP appears to be independent of this property (Lu et al. 1999).

Ds, which acts upstream of $\mathrm{Fz}$ (Yang et al. 2002), is expressed in a gradient across certain Drosophila tissues, but Ds expression across the entire epithelium of the wing but not the eye can rescue loss-of-function PCP defects, indicating that a gradient of Ds is not always necessary for PCP (Simon 2004). Ds has been implicated in cell proliferation as well as border formation in the Drosophila wing disc (Clark et al. 1995; Rodriguez 2004). Ds binds Fat directly and negatively regulates its activity (Yang et al. 2002; Matakatsu and Blair 2004), and the extracellular domain of Ds is sufficient for its function in PCP, indicating that it may act as a ligand during PCP signaling (Fig. 2; Matakatsu and Blair 2006).

Loss of Fat function leads to hyperproliferation of Drosophila imaginal discs (Mahoney et al. 1991). Fat regulates PCP at least in part by binding the transcriptional corepressor Atrophin (Fig. 2; Fanto et al. 2003). Intriguingly, it was recently shown that only the cytoplasmic tail of Fat is required for its effects on tissue growth and PCP (Matakatsu and Blair 2006). These results indicate complex interactions between the atypical cadherins in PCP, involving some homophilic and heterophilic binding and regulation of signaling cascades. Therefore, it appears that Ds, Fat, and Fmi mediate cell-cell interac- 
tions in PCP that propagate polarity cues and regulate tissue size, and are not just responsible for mechanical adhesion between cells.

\section{Atypical cadherins in vertebrate development}

The characterization of PCP protein homologs in vertebrates has recently begun. Specific homologs of cadherins involved in PCP are expressed very early in vertebrate development at the primitive streak stage and are present primarily in epithelia and CNS, with some expression within endothelia and smooth muscle (Dunne et al. 1995; Hadjantonakis et al. 1998; Nakayama et al. 1998; Cox et al. 2000). In vertebrate development, PCP components function in convergence and extension movements. Fmi mediates extension during Zebrafish gastrulation (Formstone and Mason 2005a). Fmi is upregulated in the chick neural epithelium immediately prior to neural tube closure (Formstone and Mason 2005b), a morphological event that has been shown to be regulated by other vertebrate PCP components (Goto and Keller 2002; Hikasa et al. 2002; Wallingford and Harland 2002). Knockdown of Fat1 increases cell proliferation in vertebrates (Hou et al. 2006). In addition, mice with mutant Atrophin-2 have embryonic patterning defects (Zoltewicz et al. 2004). Atrophin-1 mutations are linked to neurodegenerative disease, which appears to correlate with its nuclear localization (Nucifora et al. 2003). As Atrophin binds Fat in invertebrates, this suggests that Fat, as well as other PCP components, may also function in these processes. In the CNS, the vertebrate Fmi ortho$\log$, Celsr3, is required for the formation of axonal tracts (Tissir et al. 2005).

Another form of PCP in vertebrates is the organization of hair cell stereocilia within the inner ear. The mouse Fmi ortholog Celsr1 localizes asymmetrically along the tissue plane in chick hair cells (Davies et al. 2005), and mutant Celsr1 disrupts stereocilia architecture (Curtin et al. 2003). Interestingly, both protocadherin-15 (Pcdh15) and Cadherin-23 are mutated in the Usher I syndrome, a hereditary condition causing both deafness and vision loss (El-Amraoui and Petit 2005). Pcdh15 has been identified as the tip-link antigen, which localizes to the distal end of sensory hair bundles and could function to gate the hair cell mechanotransducer channel (Ahmed et al. 2006). Cadherin-23 is expressed in developing hair bundles at centrosomes and along the stereocilia, and is required for mechanotransduction (Siemens et al. 2004; Sollner et al. 2004; Lagziel et al. 2005), but its function is not yet clear. A Drosophila ortholog of Pcdh15, Cad99C, regulates the length of apical microvilli in ovarian follicle cells (D'Alterio et al. 2005). These studies highlight roles for a variety of cadherin subtypes in the complex organization of stereocilia, and it will be interesting to learn how their activities are coordinated and function in intercellular pathways.

The involvement of atypical cadherins in PCP illustrates the diverse morphological roles of the cadherin family. While facilitating cell-cell interaction through adhesion is an important cadherin function, they also have broader roles in cell recognition throughout tissues and participate in a complex, highly conserved signaling cascade. Atypical cadherins act to maintain polarity across tissues, regulate their size by controlling proliferation, and coordinate major morphogenetic movements in development.

\section{Conclusions}

Although cadherins almost certainly originated as a means of mechanical cell-cell adhesion, their activities have been co-opted into all aspects of tissue morphogenesis. Atypical cadherin homologs, but not classical cadherins, have recently been identified in the sponge $O$. carmela, which has a simple body plan and only epithelial tissue structures (Nichols et al. 2006). This, coupled with the expansion of the cadherin family in higher organisms, supports the idea that cadherins initially mediated cell-cell adhesion in simple organisms, but subsequently their roles diversified, in parallel with increases in their number and structural variation, to morphogenetic processes required in more complex organisms.

Cadherin expression is controlled by a variety of regulatory mechanisms at the level of gene transcription and protein trafficking and organization at the cell surface. This allows for precise, and in some cases rapid, modulation of cadherin functional activity in response to developmental cues. The diverse roles of cadherins are facilitated by their interactions with a wide range of cytoplasmic proteins, including cytoskeletal regulators, protein kinases and phosphatases, and transcriptional cofactors. Classical cadherins function in cell sorting via their differential adhesive strengths, and provide strong cell-cell adhesion to maintain the structural and functional integrity of tissues. While protocadherin-mediated cell-cell adhesion appears rather weak, it is likely that they initiate specific intracellular signaling in response to extracellular interactions; these downstream effects may be key to the development of the CNS. Atypical cadherins act within a pathway of conserved PCP components to detect and maintain polarity across tissues.

Thus, the cadherin family not only plays important roles based on their primary function in the formation of cell-cell adhesions, but has also evolved to specify cellcell recognition and sorting, boundary formation in tissues, coordination of multicell movements, and the establishment and maintenance of cell and tissue polarity. In the future, it will be important to determine how cadherin interactions that have been established in vitro translate to functions within tissues. In particular, the significance of heterophilic versus homophilic cadherin binding, the nature and regulation of linkages to the cytoskeleton, and modulation by and of signaling cascades are key questions.

\section{Acknowledgments}

We thank Adam Kwiatkowski and Lene Nejsum for comments on the manuscript. Work from the Nelson laboratory is supported by the NIH (GM35527), and a HHMI predoctoral Fellowship (to J.M.H). 


\section{References}

Abe, K., Chisaka, O., Van Roy, F., and Takeichi, M. 2004. Stability of dendritic spines and synaptic contacts is controlled by $\alpha$ N-catenin. Nat. Neurosci. 7: 357-363.

Aberle, H., Butz, S., Stappert, J., Weissig, H., Kemler, R., and Hoschuetzky, H. 1994. Assembly of the cadherin-catenin complex in vitro with recombinant proteins. J. Cell Sci. 107: 3655-3663.

Adams, C.L., Chen, Y.T., Smith, S.J., and Nelson, W.J. 1998. Mechanisms of epithelial cell-cell adhesion and cell compaction revealed by high-resolution tracking of E-cadheringreen fluorescent protein. J. Cell Biol. 142: 1105-1119.

Ahmed, Z.M., Goodyear, R., Riazuddin, S., Lagziel, A., Legan, P.K., Behra, M., Burgess, S.M., Lilley, K.S., Wilcox, E.R., Griffith, A.J., et al. 2006. The tip-link antigen, a protein associated with the transduction complex of sensory hair cells, is protocadherin-15. J. Neurosci. 26: 7022-7034.

Anastasiadis, P.Z. and Reynolds, A.B. 2001. Regulation of Rho GTPases by p120-catenin. Curr. Opin. Cell Biol. 13: 604610.

Arndt, K., Nakagawa, S., Takeichi, M., and Redies, C. 1998. Cadherin-defined segments and parasagittal cell ribbons in the developing chicken cerebellum. Mol. Cell. Neurosci. 10: 211-228.

Avizienyte, E., Wyke, A.W., Jones, R.J., McLean, G.W., Westhoff, M.A., Brunton, V.G., and Frame, M.C. 2002. Src-induced de-regulation of E-cadherin in colon cancer cells requires integrin signalling. Nat. Cell Biol. 4: 632-638.

Batlle, E., Sancho, E., Franci, C., Dominguez, D., Monfar, M., Baulida, J., and Garcia De Herreros, A. 2000. The transcription factor snail is a repressor of E-cadherin gene expression in epithelial tumour cells. Nat. Cell Biol. 2: 84-89.

Benson, D.L. and Tanaka, H. 1998. N-cadherin redistribution during synaptogenesis in hippocampal neurons. J. Neurosci. 18: 6892-6904.

Bertet, C., Sulak, L., and Lecuit, T. 2004. Myosin-dependent junction remodelling controls planar cell intercalation and axis elongation. Nature 429: 667-671.

Berx, G. and Van Roy, F. 2001. The E-cadherin/catenin complex: An important gatekeeper in breast cancer tumorigenesis and malignant progression. Breast Cancer Res. 3: 289-293.

Bozdagi, O., Shan, W., Tanaka, H., Benson, D.L., and Huntley, G.W. 2000. Increasing numbers of synaptic puncta during late-phase LTP: N-cadherin is synthesized, recruited to synaptic sites, and required for potentiation. Neuron 28: 245 259.

Bradley, R.S., Espeseth, A., and Kintner, C. 1998. NF-protocadherin, a novel member of the cadherin superfamily, is required for Xenopus ectodermal differentiation. Curr. Biol. 8: 325-334.

Brembeck, F.H., Rosario, M., and Birchmeier, W. 2006. Balancing cell adhesion and Wnt signaling, the key role of $\beta$-catenin. Curr. Opin. Genet. Dev. 16: 51-59.

Bryant, D.M. and Stow, J.L. 2004. The ins and outs of E-cadherin trafficking. Trends Cell Biol. 14: 427-434.

Cano, A., Gamallo, C., Kemp, C.J., Benito, N., Palacios, J., Quintanilla, M., and Balmain, A. 1996. Expression pattern of the cell adhesion molecules. E-cadherin, P-cadherin and $\alpha 6 \beta 4$ intergrin is altered in pre-malignant skin tumors of p53-deficient mice. Int. J. Cancer 65: 254-262.

Chen, X. and Gumbiner, B.M. 2006. Paraxial protocadherin mediates cell sorting and tissue morphogenesis by regulating C-cadherin adhesion activity. J. Cell Biol. 174: 301-313.

Chen, Y.T., Stewart, D.B., and Nelson, W.J. 1999. Coupling assembly of the E-cadherin $/ \beta$-catenin complex to efficient en- doplasmic reticulum exit and basal-lateral membrane targeting of E-cadherin in polarized MDCK cells. J. Cell Biol. 144: 687-699.

Chen, C.P., Posy, S., Ben-Shaul, A., Shapiro, L., and Honig, B.H. 2005. Specificity of cell-cell adhesion by classical cadherins: Critical role for low-affinity dimerization through $\beta$-strand swapping. Proc. Natl. Acad. Sci. 102: 8531-8536.

Chen, J., Zacharek, A., Li, Y., Li, A., Wang, L., Katakowski, M., Roberts, C., Lu, M., and Chopp, M. 2006. N-cadherin mediates nitric oxide-induced neurogenesis in young and retired breeder neurospheres. Neuroscience 140: 377-388.

Ciruna, B. and Rossant, J. 2001. FGF signaling regulates mesoderm cell fate specification and morphogenetic movement at the primitive streak. Dev. Cell 1: 37-49.

Clark, H.F., Brentrup, D., Schneitz, K., Bieber, A., Goodman, C., and Noll, M. 1995. Dachsous encodes a member of the cadherin superfamily that controls imaginal disc morphogenesis in Drosophila. Genes \& Dev. 9: 1530-1542.

Classen, A.K., Anderson, K.I., Marois, E., and Eaton, S. 2005. Hexagonal packing of Drosophila wing epithelial cells by the planar cell polarity pathway. Dev. Cell 9: 805-817.

Comijn, J., Berx, G., Vermassen, P., Verschueren, K., van Grunsven, L., Bruyneel, E., Mareel, M., Huylebroeck, D., and van Roy, F. 2001. The two-handed E box binding zinc finger protein SIP1 downregulates E-cadherin and induces invasion. Mol. Cell 7: 1267-1278.

Conacci-Sorrell, M., Simcha, I., Ben-Yedidia, T., Blechman, J., Savagner, P., and Ben-Ze'ev, A. 2003. Autoregulation of Ecadherin expression by cadherin-cadherin interactions: The roles of $\beta$-catenin signaling, Slug, and MAPK. J. Cell Biol. 163: $847-857$.

Cox, B., Hadjantonakis, A.K., Collins, J.E., and Magee, A.I. 2000. Cloning and expression throughout mouse development of mfat1, a homologue of the Drosophila tumour suppressor gene fat. Dev. Dyn. 217: 233-240.

Curtin, J.A., Quint, E., Tsipouri, V., Arkell, R.M., Cattanach, B., Copp, A.J., Henderson, D.J., Spurr, N., Stanier, P., Fisher, E.M., et al. 2003. Mutation of Celsr1 disrupts planar polarity of inner ear hair cells and causes severe neural tube defects in the mouse. Curr. Biol. 13: 1129-1133.

D'Alterio, C., Tran, D.D., Yeung, M.W., Hwang, M.S., Li, M.A., Arana, C.J., Mulligan, V.K., Kubesh, M., Sharma, P., Chase, M., et al. 2005. Drosophila melanogaster Cad99C, the orthologue of human Usher cadherin PCDH15, regulates the length of microvilli. J. Cell Biol. 171: 549-558.

Davies, A., Formstone, C., Mason, I., and Lewis, J. 2005. Planar polarity of hair cells in the chick inner ear is correlated with polarized distribution of c-flamingo-1 protein. Dev. Dyn. 233: 998-1005.

Davis, M.A., Ireton, R.C., and Reynolds, A.B. 2003. A core function for p120-catenin in cadherin turnover. J. Cell Biol. 163: 525-534.

Dawes-Hoang, R.E., Parmar, K.M., Christiansen, A.E., Phelps, C.B., Brand, A.H., and Wieschaus, E.F. 2005. Folded gastrulation, cell shape change and the control of myosin localization. Development 132: 4165-4178.

De Wever, O., Westbroek, W., Verloes, A., Bloemen, N., Bracke, M., Gespach, C., Bruyneel, E., and Mareel, M. 2004. Critical role of $\mathrm{N}$-cadherin in myofibroblast invasion and migration in vitro stimulated by colon-cancer-cell-derived TGF- $\beta$ or wounding. J. Cell Sci. 117: 4691-4703.

Drees, F., Pokutta, S., Yamada, S., Nelson, W.J., and Weis, W.I. 2005. $\alpha$-Catenin is a molecular switch that binds E-cadherin- $\beta$-catenin and regulates actin-filament assembly. Cell 123: 903-915.

Duguay, D., Foty, R.A., and Steinberg, M.S. 2003. Cadherin- 
mediated cell adhesion and tissue segregation: Qualitative and quantitative determinants. Dev. Biol. 253: 309-323.

Dunne, J., Hanby, A.M., Poulsom, R., Jones, T.A., Sheer, D., Chin, W.G., Da, S.M., Zhao, Q., Beverley, P.C., and Owen, M.J. 1995. Molecular cloning and tissue expression of FAT, the human homologue of the Drosophila fat gene that is located on chromosome 4q34-q35 and encodes a putative adhesion molecule. Genomics 30: 207-223.

Ehrlich, J.S., Hansen, M.D., and Nelson, W.J. 2002. Spatio-temporal regulation of Rac1 localization and lamellipodia dynamics during epithelial cell-cell adhesion. Dev. Cell 3: 259-270.

El-Amraoui, A. and Petit, C. 2005. Usher I syndrome: Unravelling the mechanisms that underlie the cohesion of the growing hair bundle in inner ear sensory cells. J. Cell Sci. 118: 4593-4603.

Esumi, S., Kakazu, N., Taguchi, Y., Hirayama, T., Sasaki, A., Hirabayashi, T., Koide, T., Kitsukawa, T., Hamada, S., and Yagi, T. 2005. Monoallelic yet combinatorial expression of variable exons of the protocadherin- $\alpha$ gene cluster in single neurons. Nat. Genet. 37: 171-176.

Fannon, A.M. and Colman, D.R. 1996. A model for central synaptic junctional complex formation based on the differential adhesive specificities of the cadherins. Neuron 17: 423-434.

Fanto, M. and McNeill, H. 2004. Planar polarity from flies to vertebrates. J. Cell Sci. 117: 527-533.

Fanto, M., Clayton, L., Meredith, J., Hardiman, K., Charroux, B., Kerridge, S., and McNeill, H. 2003. The tumor-suppressor and cell adhesion molecule Fat controls planar polarity via physical interactions with Atrophin, a transcriptional corepressor. Development 130: 763-774.

Formstone, C.J. and Mason, I. 2005a. Combinatorial activity of Flamingo proteins directs convergence and extension within the early zebrafish embryo via the planar cell polarity pathway. Dev. Biol. 282: 320-335.

Formstone, C.J. and Mason, I. 2005b. Expression of the Celsr/ flamingo homologue, c-fmil, in the early avian embryo indicates a conserved role in neural tube closure and additional roles in asymmetry and somitogenesis. Dev. Dyn. 232: 408413.

Foty, R.A. and Steinberg, M.S. 2005. The differential adhesion hypothesis: A direct evaluation. Dev. Biol. 278: 255-263.

Frank, M. and Kemler, R. 2002. Protocadherins. Curr. Opin. Cell Biol. 14: 557-562.

Fredette, B.J., Miller, J., and Ranscht, B. 1996. Inhibition of motor axon growth by T-cadherin substrata. Development 122: 3163-3171.

Fujita, Y., Krause, G., Scheffner, M., Zechner, D., Leddy, H.E., Behrens, J., Sommer, T., and Birchmeier, W. 2002. Hakai, a c-Cbl-like protein, ubiquitinates and induces endocytosis of the E-cadherin complex. Nat. Cell Biol. 4: 222-231.

Gallin, W.J., Edelman, G.M., and Cunningham, B.A. 1983. Characterization of L-CAM, a major cell adhesion molecule from embryonic liver cells. Proc. Natl. Acad. Sci. 80: 10381042.

Gates, J. and Peifer, M. 2005. Can 1000 reviews be wrong? Actin, $\alpha$-Catenin, and adherens junctions. Cell 123: 769-772.

Godt, D. and Tepass, U. 1998. Drosophila oocyte localization is mediated by differential cadherin-based adhesion. Nature 395: 387-391.

Goto, T. and Keller, R. 2002. The planar cell polarity gene strabismus regulates convergence and extension and neural fold closure in Xenopus. Dev. Biol. 247: 165-181.

Gumbiner, B.M. 2005. Regulation of cadherin-mediated adhesion in morphogenesis. Nat. Rev. Mol. Cell Biol. 6: 622-634.

Haas, I.G., Frank, M., Veron, N., and Kemler, R. 2005. Preseni- lin-dependent processing and nuclear function of $\gamma$-protocadherins. J. Biol. Chem. 280: 9313-9319.

Hadjantonakis, A.K., Formstone, C.J., and Little, P.F. 1998. mCelsr1 is an evolutionarily conserved seven-pass transmembrane receptor and is expressed during mouse embryonic development. Mech. Dev. 78: 91-95.

Hambsch, B., Grinevich, V., Seeburg, P.H., and Schwarz, M.K 2005. $\gamma$-Protocadherins, presenilin-mediated release of C-terminal fragment promotes locus expression. J. Biol. Chem. 280: $15888-15897$.

Hatta, K., Takagi, S., Fujisawa, H., and Takeichi, M. 1987. Spatial and temporal expression pattern of $\mathrm{N}$-cadherin cell adhesion molecules correlated with morphogenetic processes of chicken embryos. Dev. Biol. 120: 215-227.

Hayashi, T. and Carthew, R.W. 2004. Surface mechanics mediate pattern formation in the developing retina. Nature 431: 647-652.

Hazan, R.B., Phillips, G.R., Qiao, R.F., Norton, L., and Aaronson, S.A. 2000. Exogenous expression of $\mathrm{N}$-cadherin in breast cancer cells induces cell migration, invasion, and metastasis. J. Cell Biol. 148: 779-790.

Heggem, M.A. and Bradley, R.S. 2003. The cytoplasmic domain of Xenopus NF-protocadherin interacts with TAF1/set. Dev. Cell 4: 419-429.

Heyers, D., Luksch, H., and Redies, C. 2004. Selective synaptic cadherin expression by traced neurons of the chicken visual system. Neuroscience 127: 901-912.

Hikasa, H., Shibata, M., Hiratani, I., and Taira, M. 2002. The Xenopus receptor tyrosine kinase Xror2 modulates morphogenetic movements of the axial mesoderm and neuroectoderm via Wnt signaling. Development 129: 5227-5239.

Hildebrand, J.D. 2005. Shroom regulates epithelial cell shape via the apical positioning of an actomyosin network. J. Cell Sci. 118: 5191-5203.

Hirano, S., Yan, Q., and Suzuki, S.T. 1999. Expression of a novel protocadherin, OL-protocadherin, in a subset of functional systems of the developing mouse brain. J. Neurosci. 19: 9951005.

Hirano, S., Suzuki, S.T., and Redies, C. 2003. The cadherin superfamily in neural development: Diversity, function and interaction with other molecules. Front. Biosci. 8: d306d355.

Hirokawa, N., Keller III, T.C., Chasan, R., and Mooseker, M.S. 1983. Mechanism of brush border contractility studied by the quick-freeze, deep-etch method. J. Cell Biol. 96: 13251336.

Hobmayer, B., Rentzsch, F., Kuhn, K., Happel, C.M., von Laue, C.C., Snyder, P., Rothbacher, U., and Holstein, T.W. 2000. WNT signalling molecules act in axis formation in the diploblastic metazoan Hydra. Nature 407: 186-189.

Honig, M.G., Petersen, G.G., Rutishauser, U.S., and Camilli, S.J. 1998. In vitro studies of growth cone behavior support a role for fasciculation mediated by cell adhesion molecules in sensory axon guidance during development. Dev. Biol. 204: 317-326.

Hou, R., Liu, L., Anees, S., Hiroyasu, S., and Sibinga, N.E. 2006. The Fat1 cadherin integrates vascular smooth muscle cell growth and migration signals. J. Cell Biol. 173: 417-429.

Huber, A.H. and Weis, W.I. 2001. The structure of the $\beta$-catenin/E-cadherin complex and the molecular basis of diverse ligand recognition by $\beta$-catenin. Cell 105: 391-402.

Inoue, A. and Sanes, J.R. 1997. Lamina-specific connectivity in the brain: Regulation by N-cadherin, neurotrophins, and glycoconjugates. Science 276: 1428-1431.

Inoue, T., Tanaka, T., Takeichi, M., Chisaka, O., Nakamura, S., and Osumi, N. 2001. Role of cadherins in maintaining the 
compartment boundary between the cortex and striatum during development. Development 128: 561-569.

Islam, S., Carey, T.E., Wolf, G.T., Wheelock, M.J., and Johnson, K.R. 1996. Expression of N-cadherin by human squamous carcinoma cells induces a scattered fibroblastic phenotype with disrupted cell-cell adhesion. J. Cell Biol. 135: 16431654.

Iwai, Y., Usui, T., Hirano, S., Steward, R., Takeichi, M., and Uemura, T. 1997. Axon patterning requires DN-cadherin, a novel neuronal adhesion receptor, in the Drosophila embryonic CNS. Neuron 19: 77-89.

Jamora, C., DasGupta, R., Kocieniewski, P., and Fuchs, E. 2003. Links between signal transduction, transcription and adhesion in epithelial bud development. Nature 422: 317-322.

Johnson, E., Theisen, C.S., Johnson, K.R., and Wheelock, M.J. 2004. R-cadherin influences cell motility via Rho family GTPases. I. Biol. Chem. 279: 31041-31049.

Junghans, D., Haas, I.G., and Kemler, R. 2005. Mammalian cadherins and protocadherins: About cell death, synapses and processing. Curr. Opin. Cell Biol. 17: 446-452.

Jungling, K., Eulenburg, V., Moore, R., Kemler, R., Lessmann, V., and Gottmann, K. 2006. N-cadherin transsynaptically regulates short-term plasticity at glutamatergic synapses in embryonic stem cell-derived neurons. J. Neurosci. 26: 69686978.

Kamei, T., Matozaki, T., Sakisaka, T., Kodama, A., Yokoyama, S., Peng, Y.F., Nakano, K., Takaishi, K., and Takai, Y. 1999. Coendocytosis of cadherin and c-Met coupled to disruption of cell-cell adhesion in MDCK cells-Regulation by Rho, Rac and Rab small G proteins. Oncogene 18: 6776-6784.

Kane, D.A., McFarland, K.N., and Warga, R.M. 2005. Mutations in half baked/E-cadherin block cell behaviors that are necessary for teleost epiboly. Development 132: 1105-1116.

Kii, I., Amizuka, N., Shimomura, J., Saga, Y., and Kudo, A. 2004. Cell-cell interaction mediated by cadherin-11 directly regulates the differentiation of mesenchymal cells into the cells of the osteo-lineage and the chondro-lineage. J. Bone Miner. Res. 19: 1840-1849.

Kim, S.H., Yamamoto, A., Bouwmeester, T., Agius, E., and Robertis, E.M. 1998. The role of paraxial protocadherin in selective adhesion and cell movements of the mesoderm during Xenopus gastrulation. Development 125: 4681-4690.

King, N., Hittinger, C.T., and Carroll, S.B. 2003. Evolution of key cell signaling and adhesion protein families predates animal origins. Science 301: 361-363.

Klein, T.J. and Mlodzik, M. 2005. Planar cell polarization: An emerging model points in the right direction. Annu. Rev. Cell Dev. Biol. 21: 155-176.

Kobielak, A. and Fuchs, E. 2004. $\alpha$-Catenin: At the junction of intercellular adhesion and actin dynamics. Nat. Rev. Mol. Cell Biol. 5: 614-625.

Kobielak, A., Pasolli, H.A., and Fuchs, E. 2004. Mammalian formin-1 participates in adherens junctions and polymerization of linear actin cables. Nat. Cell Biol. 6: 21-30.

Kohmura, N., Senzaki, K., Hamada, S., Kai, N., Yasuda, R., Watanabe, M., Ishii, H., Yasuda, M., Mishina, M., and Yagi, T. 1998. Diversity revealed by a novel family of cadherins expressed in neurons at a synaptic complex. Neuron 20: 11371151.

Kuroda, H., Inui, M., Sugimoto, K., Hayata, T., and Asashima, M. 2002. Axial protocadherin is a mediator of prenotochord cell sorting in Xenopus. Dev. Biol. 244: 267-277.

Kussel-Andermann, P., El-Amraoui, A., Safieddine, S., Nouaille, S., Perfettini, I., Lecuit, M., Cossart, P., Wolfrum, U., and Petit, C. 2000. Vezatin, a novel transmembrane protein, bridges myosin VIIA to the cadherin-catenins complex.
EMBO J. 19: 6020-6029.

Lagziel, A., Ahmed, Z.M., Schultz, J.M., Morell, R.J., Belyantseva, I.A., and Friedman, T.B. 2005. Spatiotemporal pattern and isoforms of cadherin 23 in wild type and waltzer mice during inner ear hair cell development. Dev. Biol. 280: 295306.

Larue, L., Antos, C., Butz, S., Huber, O., Delmas, V., Dominis, M., and Kemler, R. 1996. A role for cadherins in tissue formation. Development 122: 3185-3194.

Lee, C.H., Herman, T., Clandinin, T.R., Lee, R., and Zipursky, S.L. 2001. N-cadherin regulates target specificity in the Drosophila visual system. Neuron 30: 437-450.

Lilien, J. and Balsamo, J. 2005. The regulation of cadherin-mediated adhesion by tyrosine phosphorylation/dephosphorylation of $\beta$-catenin. Curr. Opin. Cell Biol. 17: 459-465.

Lu, B., Usui, T., Uemura, T., Jan, L., and Jan, Y.N. 1999. Flamingo controls the planar polarity of sensory bristles and asymmetric division of sensory organ precursors in Drosophila. Curr. Biol. 9: 1247-1250.

Lu, B., Roegiers, F., Jan, L.Y., and Jan, Y.N. 2001. Adherens junctions inhibit asymmetric division in the Drosophila epithelium. Nature 409: 522-525.

Luo, J., Treubert-Zimmermann, U., and Redies, C. 2004. Cadherins guide migrating Purkinje cells to specific parasagittal domains during cerebellar development. Mol. Cell. Neurosci. 25: 138-152.

Maeda, M., Johnson, K.R., and Wheelock, M.J. 2005. Cadherin switching: Essential for behavioral but not morphological changes during an epithelium-to-mesenchyme transition. $J$. Cell Sci. 118: 873-887.

Mahoney, P.A., Weber, U., Onofrechuk, P., Biessmann, H., Bryant, P.J., and Goodman, C.S. 1991. The fat tumor suppressor gene in Drosophila encodes a novel member of the cadherin gene superfamily. Cell 67: 853-868.

Manabe, T., Togashi, H., Uchida, N., Suzuki, S.C., Hayakawa, Y., Yamamoto, M., Yoda, H., Miyakawa, T., Takeichi, M., and Chisaka, O. 2000. Loss of cadherin-11 adhesion receptor enhances plastic changes in hippocampal synapses and modifies behavioral responses. Mol. Cell. Neurosci. 15: 534-546.

Marambaud, P., Shioi, J., Serban, G., Georgakopoulos, A., Sarner, S., Nagy, V., Baki, L., Wen, P., Efthimiopoulos, S., Shao, Z., et al. 2002. A presenilin- $1 / \gamma$-secretase cleavage releases the E-cadherin intracellular domain and regulates disassembly of adherens junctions. EMBO J. 21: 1948-1956.

Marambaud, P., Wen, P.H., Dutt, A., Shioi, J., Takashima, A., Siman, R., and Robakis, N.K. 2003. A CBP binding transcriptional repressor produced by the PS $1 / \varepsilon$-cleavage of $\mathrm{N}$-cadherin is inhibited by PS1 FAD mutations. Cell 114: 635-645.

Maretzky, T., Reiss, K., Ludwig, A., Buchholz, J., Scholz, F., Proksch, E., de Strooper, B., Hartmann, D., and Saftig, P. 2005. ADAM10 mediates E-cadherin shedding and regulates epithelial cell-cell adhesion, migration, and $\beta$-catenin translocation. Proc. Nat1. Acad. Sci. 102: 9182-9187.

Marthiens, V., Gavard, J., Padilla, F., Monnet, C., Castellani, V., Lambert, M., and Mege, R.M. 2005. A novel function for cadherin-11 in the regulation of motor axon elongation and fasciculation. Mol. Cell. Neurosci. 28: 715-726.

Matakatsu, H. and Blair, S.S. 2004. Interactions between Fat and Dachsous and the regulation of planar cell polarity in the Drosophila wing. Development 131: 3785-3794.

Matakatsu, H. and Blair, S.S. 2006. Separating the adhesive and signaling functions of the Fat and Dachsous protocadherins. Development 133: 2315-2324.

Medina, A., Swain, R.K., Kuerner, K.M., and Steinbeisser, H. 2004. Xenopus paraxial protocadherin has signaling functions and is involved in tissue separation. EMBO J. 23: 3249- 
3258.

Moeller, M.J., Soofi, A., Braun, G.S., Li, X., Watzl, C., Kriz, W., and Holzman, L.B. 2004. Protocadherin FAT1 binds Ena/ VASP proteins and is necessary for actin dynamics and cell polarization. EMBO J. 23: 3769-3779.

Morishita, H., Kawaguchi, M., Murata, Y., Seiwa, C., Hamada, S., Asou, H., and Yagi, T. 2004. Myelination triggers local loss of axonal CNR/protocadherin $\alpha$ family protein expression. Eur. J. Neurosci. 20: 2843-2847.

Murakami, T., Hijikata, T., Matsukawa, M., Ishikawa, H., and Yorifuji, H. 2006. Zebrafish protocadherin 10 is involved in paraxial mesoderm development and somitogenesis. Dev. Dyn. 235: 506-514.

Murata, Y., Hamada, S., Morishita, H., Mutoh, T., and Yagi, T. 2004. Interaction with protocadherin- $\gamma$ regulates the cell surface expression of protocadherin- $\alpha$. J. Biol. Chem. 279: $49508-49516$.

Mutoh, T., Hamada, S., Senzaki, K., Murata, Y., and Yagi, T. 2004. Cadherin-related neuronal receptor 1 (CNR1) has cell adhesion activity with $\beta 1$ integrin mediated through the RGD site of CNR1. Exp. Cell Res. 294: 494-508.

Nakayama, M., Nakajima, D., Nagase, T., Nomura, N., Seki, N., and Ohara, O. 1998. Identification of high-molecularweight proteins with multiple EGF-like motifs by motif-trap screening. Genomics 51: 27-34.

Nichols, S.A., Dirks, W., Pearse, J.S., and King, N. 2006. Early evolution of animal cell signaling and adhesion genes. Proc. Nat1. Acad. Sci. 103: 12451-12456.

Nieman, M.T., Prudoff, R.S., Johnson, K.R., and Wheelock, M.J. 1999. N-cadherin promotes motility in human breast cancer cells regardless of their E-cadherin expression. J. Cell Biol. 147: 631-644.

Niessen, C.M. and Gumbiner, B.M. 2002. Cadherin-mediated cell sorting not determined by binding or adhesion specificity. J. Cell Biol. 156: 389-399.

Nollet, F., Kools, P., and van Roy, F. 2000. Phylogenetic analysis of the cadherin superfamily allows identification of six major subfamilies besides several solitary members. J. Mol. Biol. 299: 551-572.

Noren, N.K., Liu, B.P., Burridge, K., and Kreft, B. 2000. p120 catenin regulates the actin cytoskeleton via Rho family GTPases. J. Cell Biol. 150: 567-580.

Nose, A., Nagafuchi, A., and Takeichi, M. 1988. Expressed recombinant cadherins mediate cell sorting in model systems. Cell 54: 993-1001.

Nucifora Jr., F.C., Ellerby, L.M., Wellington, C.L., Wood, J.D., Herring, W.J., Sawa, A., Hayden, M.R., Dawson, V.L., Dawson, T.M., and Ross, C.A. 2003. Nuclear localization of a non-caspase truncation product of atrophin-1, with an expanded polyglutamine repeat, increases cellular toxicity. $J$. Biol. Chem. 278: 13047-13055.

Obata, S., Sago, H., Mori, N., Rochelle, J.M., Seldin, M.F., Davidson, M., St John, T., Taketani, S., and Suzuki, S.T. 1995. Protocadherin Pcdh2 shows properties similar to, but distinct from, those of classical cadherins. J. Cell Sci. 108: 3765-3773.

Oda, H., Tsukita, S., and Takeichi, M. 1998. Dynamic behavior of the cadherin-based cell-cell adhesion system during Drosophila gastrulation. Dev. Biol. 203: 435-450.

Patel, S.D., Ciatto, C., Chen, C.P., Bahna, F., Rajebhosale, M., Arkus, N., Schieren, I., Jessell, T.M., Honig, B., Price, S.R., et al. 2006. Type II cadherin ectodomain structures: Implications for classical cadherin specificity. Cell 124: 1255-1268.

Paul, R., Ewing, C.M., Robinson, J.C., Marshall, F.F., Johnson, K.R., Wheelock, M.J., and Isaacs, W.B. 1997. Cadherin-6, a cell adhesion molecule specifically expressed in the proxi- mal renal tubule and renal cell carcinoma. Cancer Res. 57: 2741-2748.

Peyrieras, N., Hyafil, F., Louvard, D., Ploegh, H.L., and Jacob, F. 1983. Uvomorulin: A nonintegral membrane protein of early mouse embryo. Proc. Natl. Acad. Sci. 80: 6274-6277.

Piccoli, G., Rutishauser, U., and Bruses, J.L. 2004. N-cadherin juxtamembrane domain modulates voltage-gated $\mathrm{Ca}^{2+}$ current via RhoA GTPase and Rho-associated kinase. J. Neurosci. 24: 10918-10923.

Pilot, F., Philippe, J.M., Lemmers, C., and Lecuit, T. 2006. Spatial control of actin organization at adherens junctions by a synaptotagmin-like protein. Nature 442: 580-584.

Pollard, T.D. and Borisy, G.G. 2003. Cellular motility driven by assembly and disassembly of actin filaments. Cell 112: 453465.

Price, S.R., De Marco Garcia, N.V., Ranscht, B., and Jessell, T.M. 2002. Regulation of motor neuron pool sorting by differential expression of type II cadherins. Cell 109: 205-216.

Qi, J., Chen, N., Wang, J., and Siu, C.H. 2005. Transendothelial migration of melanoma cells involves $\mathrm{N}$-cadherin-mediated adhesion and activation of the $\beta$-catenin signaling pathway. Mol. Biol. Cell 16: 4386-4397.

Radice, G.L., Rayburn, H., Matsunami, H., Knudsen, K.A., Takeichi, M., and Hynes, R.O. 1997. Developmental defects in mouse embryos lacking N-cadherin. Dev. Biol. 181: 6478.

Rashid, D., Newell, K., Shama, L., and Bradley, R. 2006. A requirement for NF-protocadherin and TAF1/Set in cell adhesion and neural tube formation. Dev. Biol. 291: 170-181.

Redies, C., Inuzuka, H., and Takeichi, M. 1992. Restricted expression of $\mathrm{N}$ - and R-cadherin on neurites of the developing chicken CNS. J. Neurosci. 12: 3525-3534.

Redies, C., Engelhart, K., and Takeichi, M. 1993. Differential expression of $\mathrm{N}$ - and R-cadherin in functional neuronal systems and other structures of the developing chicken brain. $J$. Comp. Neurol. 333: 398-416.

Redies, C., Ast, M., Nakagawa, S., Takeichi, M., Martinez-dela-Torre, M., and Puelles, L. 2000. Morphologic fate of diencephalic prosomeres and their subdivisions revealed by mapping cadherin expression. J. Comp. Neurol. 421: 481-514.

Redies, C., Vanhalst, K., and Roy, F. 2005. $\delta$-Protocadherins: Unique structures and functions. Cell. Mol. Life Sci. 62: 2840-2852.

Reintsch, W.E., Habring-Mueller, A., Wang, R.W., Schohl, A., and Fagotto, F. 2005. $\beta$-Catenin controls cell sorting at the notochord-somite boundary independently of cadherin-mediated adhesion. J. Cell Biol. 170: 675-686.

Reiss, K., Maretzky, T., Ludwig, A., Tousseyn, T., de Strooper, B., Hartmann, D., and Saftig, P. 2005. ADAM10 cleavage of $\mathrm{N}$-cadherin and regulation of cell-cell adhesion and $\beta$-catenin nuclear signalling. EMBO J. 24: 742-752.

Reiss, K., Maretzky, T., Haas, I.G., Schulte, M., Ludwig, A., Frank, M., and Saftig, P. 2006. Regulated ADAM10-dependent ectodomain shedding of $\gamma$-protocadherin C3 modulates cell-cell adhesion. J. Biol. Chem. 281: 21735-21744.

Richards, E.J. 2006. Inherited epigenetic variation-Revisiting soft inheritance. Nat. Rev. Genet. 7: 395-401.

Riehl, R., Johnson, K., Bradley, R., Grunwald, G.B., Cornel, E., Lilienbaum, A., and Holt, C.E. 1996. Cadherin function is required for axon outgrowth in retinal ganglion cells in vivo. Neuron 17: 837-848.

Rodriguez, I. 2004. The dachsous gene, a member of the cadherin family, is required for $\mathrm{Wg}$-dependent pattern formation in the Drosophila wing disc. Development 131: 3195-3206.

Sano, K., Tanihara, H., Heimark, R.L., Obata, S., Davidson, M., St John, T., Taketani, S., and Suzuki, S. 1993. Protocadher- 
ins: A large family of cadherin-related molecules in central nervous system. EMBO J. 12: 2249-2256.

Senzaki, K., Ogawa, M., and Yagi, T. 1999. Proteins of the CNR family are multiple receptors for Reelin. Cell 99: 635-647.

Shimamura, K., Takahashi, T., and Takeichi, M. 1992. E-cadherin expression in a particular subset of sensory neurons. Dev. Biol. 152: 242-254.

Shimazui, T., Giroldi, L.A., Bringuier, P.P., Oosterwijk, E., and Schalken, J.A. 1996. Complex cadherin expression in renal cell carcinoma. Cancer Res. 56: 3234-3237.

Shimizu, T., Yabe, T., Muraoka, O., Yonemura, S., Aramaki, S., Hatta, K., Bae, Y.K., Nojima, H., and Hibi, M. 2005. E-cadherin is required for gastrulation cell movements in zebrafish. Mech. Dev. 122: 747-763.

Shimoyama, Y., Tsujimoto, G., Kitajima, M., and Natori, M. 2000. Identification of three human type-II classic cadherins and frequent heterophilic interactions between different subclasses of type-II classic cadherins. Biochem. J. 349: 159167.

Siemens, J., Lillo, C., Dumont, R.A., Reynolds, A., Williams, D.S., Gillespie, P.G., and Muller, U. 2004. Cadherin 23 is a component of the tip link in hair-cell stereocilia. Nature 428: 950-955.

Simon, M.A. 2004. Planar cell polarity in the Drosophila eye is directed by graded Four-jointed and Dachsous expression. Development 131: 6175-6184.

Sollner, C., Rauch, G.J., Siemens, J., Geisler, R., Schuster, S.C., Muller, U., and Nicolson, T. 2004. Mutations in cadherin 23 affect tip links in zebrafish sensory hair cells. Nature 428: 955-959.

Stemmler, M.P., Hecht, A., and Kemler, R. 2005. E-cadherin intron 2 contains cis-regulatory elements essential for gene expression. Development 132: 965-976.

Stoykova, A., Gotz, M., Gruss, P., and Price, J. 1997. Pax6-dependent regulation of adhesive patterning, R-cadherin expression and boundary formation in developing forebrain. Development 124: 3765-3777.

Strathdee, G. 2002. Epigenetic versus genetic alterations in the inactivation of E-cadherin. Semin. Cancer Biol. 12: 373-379.

Sugino, H., Hamada, S., Yasuda, R., Tuji, A., Matsuda, Y., Fujita, M., and Yagi, T. 2000. Genomic organization of the family of CNR cadherin genes in mice and humans. Genomics 63: 75-87.

Suyama, K., Shapiro, I., Guttman, M., and Hazan, R.B. 2002. A signaling pathway leading to metastasis is controlled by $\mathrm{N}$ cadherin and the FGF receptor. Cancer Cell 2: 301-314.

Suzuki, S.C., Inoue, T., Kimura, Y., Tanaka, T., and Takeichi, M. 1997. Neuronal circuits are subdivided by differential expression of type-II classic cadherins in postnatal mouse brains. Mol. Cell. Neurosci. 9: 433-447.

Takeichi, M. 1988. The cadherins: Cell-cell adhesion molecules controlling animal morphogenesis. Development 102: 639655.

Tanaka, H., Shan, W., Phillips, G.R., Arndt, K., Bozdagi, O., Shapiro, L., Huntley, G.W., Benson, D.L., and Colman, D.R. 2000. Molecular modification of $\mathrm{N}$-cadherin in response to synaptic activity. Neuron 25: 93-107.

Tang, L., Hung, C.P., and Schuman, E.M. 1998. A role for the cadherin family of cell adhesion molecules in hippocampal long-term potentiation. Neuron 20: 1165-1175.

Tanoue, T. and Takeichi, M. 2004. Mammalian Fatl cadherin regulates actin dynamics and cell-cell contact. J. Cell Biol. 165: 517-528.

Thiery, J.P. 2002. Epithelial-mesenchymal transitions in tumour progression. Nat. Rev. Cancer 2: 442-454.

Tissir, F., Bar, I., Jossin, Y., De Backer, O., and Goffinet, A.M.
2005. Protocadherin Celsr3 is crucial in axonal tract development. Nat. Neurosci. 8: 451-457.

Togashi, H., Abe, K., Mizoguchi, A., Takaoka, K., Chisaka, O., and Takeichi, M. 2002. Cadherin regulates dendritic spine morphogenesis. Neuron 35: 77-89.

Triana-Baltzer, G.B. and Blank, M. 2006. Cytoplasmic domain of protocadherin- $\alpha$ enhances homophilic interactions and recognizes cytoskeletal elements. J. Neurobiol. 66: 393-407.

Uchida, N., Honjo, Y., Johnson, K.R., Wheelock, M.J., and Takeichi, M. 1996. The catenin/cadherin adhesion system is localized in synaptic junctions bordering transmitter release zones. J. Cell Biol. 135: 767-779.

Uemura, K., Kihara, T., Kuzuya, A., Okawa, K., Nishimoto, T., Bito, H., Ninomiya, H., Sugimoto, H., Kinoshita, A., and Shimohama, S. 2006a. Activity-dependent regulation of $\beta$-catenin via $\varepsilon$-cleavage of $\mathrm{N}$-cadherin. Biochem. Biophys. Res. Commun. 345: 951-958.

Uemura, K., Kihara, T., Kuzuya, A., Okawa, K., Nishimoto, T., Ninomiya, H., Sugimoto, H., Kinoshita, A., and Shimohama, S. 2006b. Characterization of sequential N-cadherin cleavage by ADAM10 and PS1. Neurosci. Lett. 402: 278-283.

Unterseher, F., Hefele, J.A., Giehl, K., De Robertis, E.M., Wedlich, D., and Schambony, A. 2004. Paraxial protocadherin coordinates cell polarity during convergent extension via Rho A and JNK. EMBO J. 23: 3259-3269.

Usui, T., Shima, Y., Shimada, Y., Hirano, S., Burgess, R.W., Schwarz, T.L., Takeichi, M., and Uemura, T. 1999. Flamingo, a seven-pass transmembrane cadherin, regulates planar cell polarity under the control of Frizzled. Cell 98: 585595.

Vaezi, A., Bauer, C., Vasioukhin, V., and Fuchs, E. 2002. Actin cable dynamics and Rho/Rock orchestrate a polarized cytoskeletal architecture in the early steps of assembling a stratified epithelium. Dev. Cell 3: 367-381.

Vanhalst, K., Kools, P., Staes, K., van Roy, F., and Redies, C. 2005. $\delta$-Protocadherins: A gene family expressed differentially in the mouse brain. Cell. Mol. Life Sci. 62: 1247-1259.

Wallingford, J.B. and Harland, R.M. 2002. Neural tube closure requires Dishevelled-dependent convergent extension of the midline. Development 129: 5815-5825.

Wang, X., Su, H., and Bradley, A. 2002a. Molecular mechanisms governing Pcdh- $\gamma$ gene expression: Evidence for a multiple promoter and cis-alternative splicing model. Genes \& Dev. 16: $1890-1905$.

Wang, X., Weiner, J.A., Levi, S., Craig, A.M., Bradley, A., and Sanes, J.R. 2002b. $\gamma$ Protocadherins are required for survival of spinal interneurons. Neuron 36: 843-854.

Wang, F., Dumstrei, K., Haag, T., and Hartenstein, V. 2004. The role of DE-cadherin during cellularization, germ layer formation and early neurogenesis in the Drosophila embryo. Dev. Biol. 270: 350-363.

Weis, W.I. and Nelson, W.J. 2006. Re-solving the cadherincatenin-actin conundrum. J. Biol. Chem. Epub Sept. 27, 2006; doi: 10.1074/jbc.R600027200.

Wessells, N.K., Spooner, B.S., Ash, J.F., Bradley, M.O., Luduena, M.A., Taylor, E.L., Wrenn, J.T., and Yamaa, K. 1971. Microfilaments in cellular and developmental processes. Science 171: 135-143.

Wheelock, M.J., Buck, C.A., Bechtol, K.B., and Damsky, C.H. 1987. Soluble 80-kd fragment of cell-CAM 120/80 disrupts cell-cell adhesion. J. Cell. Biochem. 34: 187-202.

Williams, E.J., Furness, J., Walsh, F.S., and Doherty, P. 1994. Activation of the FGF receptor underlies neurite outgrowth stimulated by L1, N-CAM, and N-cadherin. Neuron 13: 583 594.

Williams, E.J., Williams, G., Howell, F.V., Skaper, S.D., Walsh, 
Halbleib and Nelson

F.S., and Doherty, P. 2001. Identification of an N-cadherin motif that can interact with the fibroblast growth factor receptor and is required for axonal growth. J. Biol. Chem. 276: 43879-43886.

Wodarz, A. 2005. Molecular control of cell polarity and asymmetric cell division in Drosophila neuroblasts. Curr. Opin. Cell Biol. 17: 475-481.

Wohrn, J.C., Nakagawa, S., Ast, M., Takeichi, M., and Redies, C. 1999. Combinatorial expression of cadherins in the tectum and the sorting of neurites in the tectofugal pathways of the chicken embryo. Neuroscience 90: 985-1000.

Wu, Q. and Maniatis, T. 1999. A striking organization of a large family of human neural cadherin-like cell adhesion genes. Cell 97: 779-790.

Wu, Q., Zhang, T., Cheng, J.F., Kim, Y., Grimwood, J., Schmutz, J., Dickson, M., Noonan, J.P., Zhang, M.Q., Myers, R.M., et al. 2001. Comparative DNA sequence analysis of mouse and human protocadherin gene clusters. Genome Res. 11: 389404.

Xian, W., Schwertfeger, K.L., Vargo-Gogola, T., and Rosen, J.M. 2005. Pleiotropic effects of FGFR1 on cell proliferation, survival, and migration in a 3D mammary epithelial cell model. J. Cell Biol. 171: 663-673.

Yagi, T. and Takeichi, M. 2000. Cadherin superfamily genes: Functions, genomic organization, and neurologic diversity. Genes \& Dev. 14: 1169-1180.

Yamada, S., Pokutta, S., Drees, F., Weis, W.I., and Nelson, W.J. 2005. Deconstructing the cadherin-catenin-actin complex. Cell 123: 889-901.

Yamamoto, A., Amacher, S.L., Kim, S.H., Geissert, D., Kimmel, C.B., and De Robertis, E.M. 1998. Zebrafish paraxial protocadherin is a downstream target of spadetail involved in morphogenesis of gastrula mesoderm. Development 125: 3389-3397.

Yamamoto, A., Kemp, C., Bachiller, D., Geissert, D., and De Robertis, E.M. 2000. Mouse paraxial protocadherin is expressed in trunk mesoderm and is not essential for mouse development. Genesis 27: 49-57.

Yamashita, Y.M., Jones, D.L., and Fuller, M.T. 2003. Orientation of asymmetric stem cell division by the APC tumor suppressor and centrosome. Science 301: 1547-1550.

Yang, C.H., Axelrod, J.D., and Simon, M.A. 2002. Regulation of Frizzled by fat-like cadherins during planar polarity signaling in the Drosophila compound eye. Cell 108: 675-688.

Yoshida, C. and Takeichi, M. 1982. Teratocarcinoma cell adhesion: Identification of a cell-surface protein involved in calcium-dependent cell aggregation. Cell 28: 217-224.

Zhang, J., Niu, C., Ye, L., Huang, H., He, X., Tong, W.G., Ross, J., Haug, J., Johnson, T., Feng, J.Q., et al. 2003. Identification of the haematopoietic stem cell niche and control of the niche size. Nature 425: 836-841.

Zoltewicz, J.S., Stewart, N.J., Leung, R., and Peterson, A.S 2004. Atrophin 2 recruits histone deacetylase and is required for the function of multiple signaling centers during mouse embryogenesis. Development 131: 3-14. 


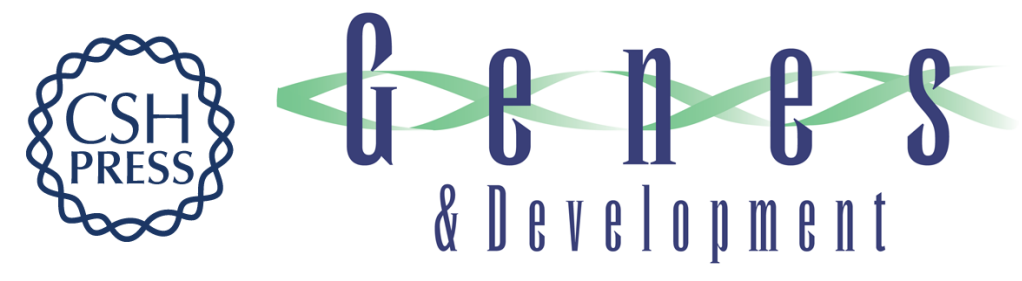

\section{Cadherins in development: cell adhesion, sorting, and tissue morphogenesis}

Jennifer M. Halbleib and W. James Nelson

Genes Dev. 2006, 20:

Access the most recent version at doi:10.1101/gad.1486806

References This article cites 190 articles, 74 of which can be accessed free at: http://genesdev.cshlp.org/content/20/23/3199.full.html\#ref-list-1

License

Email Alerting

Receive free email alerts when new articles cite this article - sign up in the box at the top Service right corner of the article or click here.

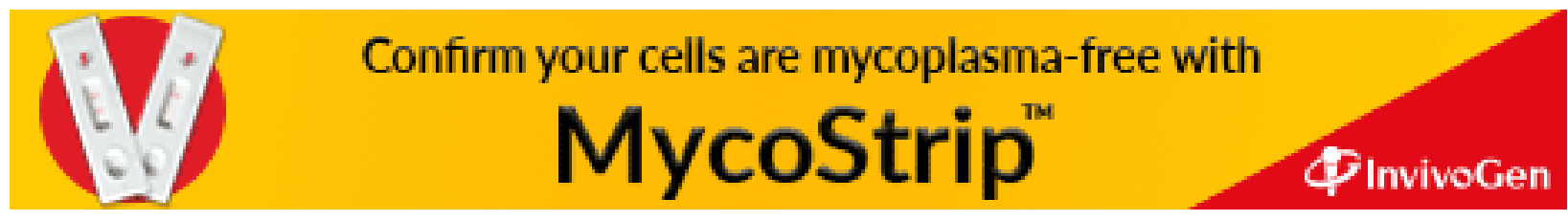

